\title{
Determinants of species richness and similarity of species composition of land snail communities on Kimberley islands
}

\author{
L.A. Gibson' ${ }^{1}$ and F. Köhler ${ }^{1,2}$ \\ 1 Department of Environment and Conservation, Science Division, PO Box 51, Wanneroo, \\ Western Australia 6946, Australia. \\ ${ }^{2}$ Australian Museum, 6 College Street, Sydney, New South Wales 2010, Australia \\ Email: Lesley.Gibson@dec.wa.gov.au
}

\begin{abstract}
We investigated patterns in species richness and similarity in species composition of land snail communities in relation to biogeographic and environmental gradients on continental islands along the Kimberley coastline of Western Australia. The camaenid land snails demonstrated high overall species richness, restricted geographical ranges (mostly to a single island) and almost complete turnover of species among islands. In comparison, the overall number of the smaller non-camaenid land snail species was much lower. They also had much wider distributions and a lower level of species turnover among islands. These results are consistent with the differing dispersal abilities of the two groups, one fostering in situ speciation and the other inter-island colonisation. We also show that dispersal ability was not the only driver of species richness and composition of land snail species on islands, but that rainfall, island area and availability of habitat also played a role. Rainfall was the major environmental driver of richness and composition for both groups of land snails. Rainfall was also highly correlated with extent of rainforest cover, habitat that provides a suitable micro-climate for snails and additional ecological niches compared to more open habitats.
\end{abstract}

KEYWORDS: Pulmonata, island biogeography, land snail diversity, Camaenidae, gastropod richness

\section{INTRODUCTION}

The Kimberley region of north-western Australia is recognised as a national biodiversity hotspot, due largely to the number of endemic plant and animal species it supports (http://www.environment. gov.au/biodiversity/hotspots/national-hotspots. $\mathrm{htm})$. A relatively little-known, yet significant, component of this diversity and high endemism, are the terrestrial gastropods (or land snails) of the region. Surveys conducted between 1987 and 1989 in the rainforests of the Kimberley (McKenzie et al. 1991a) uncovered a large diversity of land snail species (Solem 1991). Earlier work in the Kimberley also showed that the snail fauna in the Kimberley is dominated by one family, the Camaenidae (Solem 1981a, 1981b, 1984, 1985, 1988a, 1991). The remaining species, which represent various families of nonmarine gastropods, are here referred to as 'noncamaenids'. They account for only a comparatively small proportion of the overall diversity of land snail species in the region (Solem 1988b, 1991). A further striking difference between the two groups of land snails is that most of the camaenids are narrow-range endemics, with an average range size of approximately $20 \mathrm{~km}$ (Solem 1991), while the noncamaenids generally have expansive ranges with geographic distributions extending well outside the Kimberley region (Solem 1988b, 1991). The narrow range endemism observed in the camaenids has been attributed to their poor dispersal capability (Solem and McKenzie 1991).

Highly fragmented and isolated environments, such as island archipelagos, often display high levels of endemism and species diversity (Losos and Ricklefs 2010). One of the factors believed to contribute to the high diversity of camaenid land snails in the Kimberley is the multiplicity of refugia distributed across the region in the form of rainforest patches (Solem 1991). Created by climate fluctuations throughout the Quaternary and Mid to Late Tertiary (Bowler 1982), these patches essentially have been acting as habitat islands whereby gene flow is restricted by intervening unsuitable habitat, resulting in allopatric patterns of speciation and endemism in the isolated refuges (Cameron 1992). The high levels of endemism of land snails in the limestone karsts of Malaysia has 
been similarly explained (Clements et al. 2008), as well as land snails occurring on islands or within island archipelagos (e.g. Cowie 1995; WelterSchultes and Williams 1999; Chiba 2007; Cook 2008; Overton et al. 2009).

Centres of high land snail diversity in the Kimberley region largely correspond with the wetter coastal areas of the north (Solem 1991). Also within this area are extensive island archipelagos which, created by the flooding of an ancient coastline, represent much of the adjacent mainland's geological surfaces and vegetation communities (May and McKenzie 2002). The rainforest survey of the late 1980s included a small number of these islands, but aside from a few opportunistic collections, the diversity of land snails on the majority of islands has remained largely unknown until recently.

From 2007 to 2010, the Kimberley Island Survey (KIS) of biodiversity was conducted on a selection of the largest islands in order to test assumptions of islands acting as natural refuges, particularly for those species susceptible to escalating threatening processes on the Kimberley mainland. Land snails were selected as one of the target groups, because they are considered to be indicators for other restricted range invertebrate groups. Their disjunct distributions on the mainland make them particularly sensitive to processes that alter their optimal habitat, such as changed fire regimes, grazing and introduction of weeds. Descriptions and distributions of each camaenid and noncamaenid land snail species encountered during this survey have been published elsewhere (Köhler 2010a, 2010b, 2011a, 2011b, 2011c; Köhler et al. 2012). Briefly, a total of 104 camaenid species (83 new) in 15 genera (5 new) were recorded from the islands (including a number of additional islands outside of the survey area) with most species found to be island endemics (Köhler 2011b). Additionally, 21 non-camaenid land snails were recorded from the islands, with four of these being freshwater species (Köhler et al. 2012).

Here, we investigated patterns in species richness and similarity in species composition of land snails recorded during the above survey in relation to biogeographic and environmental gradients. We were interested in examining if the speciesarea relationship held for the Kimberley island snail fauna as has been found on other island archipelagos (e.g. Cowie 1995; Welter-Schultes and Williams 1999; Triantis et al. 2005; Chiba 2007), as well as the effect of island isolation on snail richness and composition. We expected that the high levels of local endemism of camaenid land snails observed on the adjacent mainland (Solem 1991) would be reflected in the island fauna with a high turnover of species among islands. In contrast, we anticipated a much lower level of turnover in the more widespread non-camaenid species. The conservation implications of the results are discussed, particularly with regard to issues involving short-range endemism.

\section{METHODS}

\section{STUDY AREA}

We selected 24 of the largest islands for sampling, targeting those with a variety of geological surfaces, as well as ensuring geographic coverage from north to south (see Gibson and McKenzie 2012). These islands extend from Sir Graham Moore Island off the Anjo Peninsula in the north to Sunday Island off Cape Leveque in the south, and to Adolphus Island in the Cambridge Gulf in the east. They include islands from the Bonaparte and Buccaneer Archipelagos, as well as several other island groups (Figure 1).

Geological and detailed vegetation descriptions of the islands are given in Gibson and McKenzie (2012). Briefly, sandstone and volcanic strata structure the island landscapes. The sandstones tend to give rise to rugged, dissected terrains, while the volcanics usually produce a more rounded and gently undulating topography. Tertiary duricrusts occur as mesas and dissected tablelands on some islands, capping volcanic, sandstone or doleritic strata. Broad vegetation communities on the islands include tropical savannas, hummock grassland, rainforest, coastal tussock grassland, riparian paperbark woodlands and mangroves.

The Kimberley experiences a tropical monsoon climate with two distinct seasons: a dry season extending from around April to October, and a wet season from November to March when almost all rainfall occurs. Cyclonic activity is also a feature of the climate. Average annual rainfall ranges from $>1,500 \mathrm{~mm}$ at Mitchell Plateau to $<800 \mathrm{~mm}$ at Cape Leveque (http://www.bom.gov.au). Daily temperatures range from $23-38^{\circ} \mathrm{C}$ throughout the year, with high relative humidity peaking during the wet season.

\section{SAMPLING AND IDENTIFICATION}

A comprehensive description of the survey implementation is given in Gibson and McKenzie (2012). In summary, campsites on the islands were selected using information on geology and vegetation from maps, local knowledge, satellite imagery and a reconnaissance flight. Survey teams (see Gibson and McKenzie 2012) needed to be placed within walking distance of as many habitat/ vegetation types as possible. Two campsites were needed to access the environmental variation of 


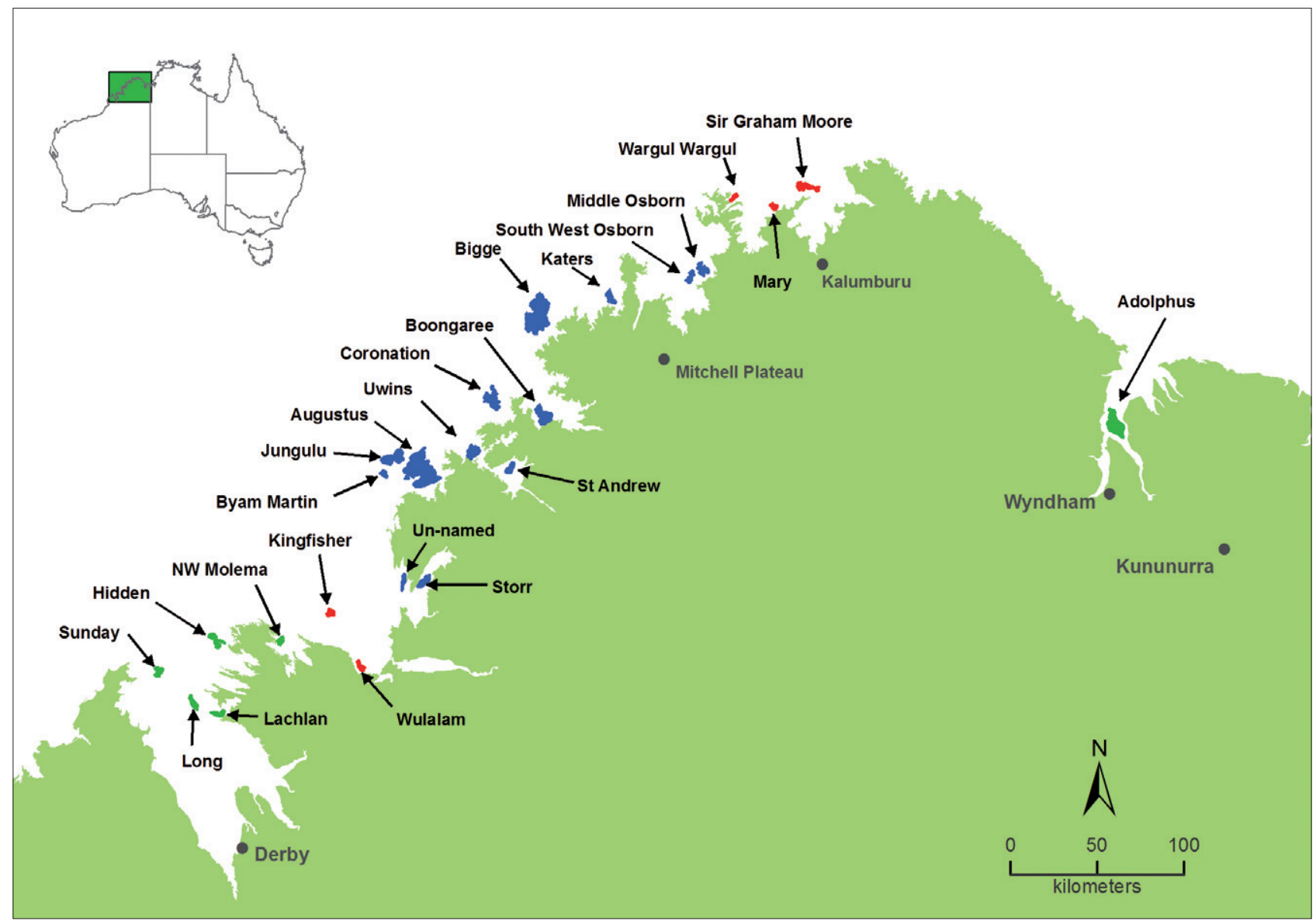

FIGURE $1 \quad$ Location of Kimberley islands selected for a survey of their biodiversity assets along the north-west coast of Australia. Island colour indicates its average annual rainfall (green $<900 \mathrm{~mm}$, red 900 to 1,000 $\mathrm{mm}$, and blue $>1,000 \mathrm{~mm}$ ).

the largest islands. All sites were presented to the Traditional Owners for their approval. In the dry season, campsites were accessed by helicopter and sampled over a six-day period. Sites were then revisited in the wet season using a combination of charter boat and helicopter, and sampled over a single day and night. In total, 31 campsites were sampled over four dry and three wet seasons from 2007 to 2010.

During the dry season, aestivating snails were collected by raking leaf litter, lifting rocks, digging, searching under logs and examining tree crevices. Litter samples were also collected for subsequent sorting in the laboratory. Usually, several locations were searched for land snails within walking distance of the campsite. Search emphasis was placed on rainforest vegetation, including vine thickets, and in gullies and gorges, i.e. areas of high humidity where snails tend to frequently occur. During the wet season, snails were more active, particularly during and following rain, and could be collected directly from the substrate.
All material was sorted, labeled, given preliminary identifications, photographed and catalogued by V. Kessner and sent on to the Australian Museum for formal description by F. Köhler. Details on the methods of identification are given in Köhler (2011b), but basically involved initial comparisons with type specimens, followed by measurement of shell parameters, description of the genital anatomy (following dissection) and radula, and molecular analyses via DNA extraction. Voucher specimens are lodged at the Western Australian Museum in Perth and at the Australian Museum in Sydney.

\section{ISLAND ATTRIBUTES}

We selected a number of attributes that have been shown to influence species richness and assemblage composition of land snails (e.g. Solem and McKenzie 1991; Cowie 1995; Welter-Schultes and Williams 1999; Triantis et al. 2005; Clements et al. 2008; Overton et al. 2009) (Table 1). These include island area, distance to a larger landmass, average 
TABLE $1 \quad$ Values of the island attributes selected for the analysis of species richness of land snails sampled along the Kimberley coast. Key: Distance - distance to nearest larger landmass, Area - area of island, Elevation - maximum elevation, Boulder - extent of rock scree $0=$ flat; 1 = rounded, soil-mantled hill slopes and plateaux, narrow scree; 2 = shallow joints, wide ledges, moderate scree; 3 = massive scree, deep joints and scarp country), Rainfall - average annual rainfall, Rainforest - extent of rainforest $(0=$ none present; 1 = rainforest present on island but not sampled; 2 = patchy rainforest sampled; 3 = well developed rainforest sampled), Sites - number of locations sampled on an island.

\begin{tabular}{|c|c|c|c|c|c|c|c|}
\hline Island & $\begin{array}{l}\text { Distance } \\
(\mathrm{km})\end{array}$ & Area (ha) & $\begin{array}{l}\text { Elevation } \\
\text { (m) }\end{array}$ & Boulder & $\begin{array}{l}\text { Rainfall } \\
(\mathrm{mm})\end{array}$ & Rainforest & Sites \\
\hline Adolphus & 1.96 & 4157 & 244 & 2 & 827 & 1 & 9 \\
\hline Augustus & 1.79 & 18992 & 181 & 3 & 1170 & 3 & 16 \\
\hline Bigge & 2.97 & 17096 & 138 & 3 & 1103 & 3 & 23 \\
\hline Boongaree & 0.24 & 4215 & 235 & 3 & 1138 & 3 & 16 \\
\hline Coronation & 5.94 & 3817 & 153 & 2 & 1141 & 3 & 28 \\
\hline Hidden & 1.48 & 1901 & 127 & 3 & 839 & 0 & 4 \\
\hline Jungulu & 3.23 & 4841 & 95 & 3 & 1148 & 2 & 18 \\
\hline Katers & 1.4 & 1718 & 101 & 3 & 1069 & 3 & 14 \\
\hline Kingfisher & 15.47 & 367 & 82 & 1 & 943 & 1 & 9 \\
\hline Lachlan & 0.17 & 1181 & 93 & 2 & 787 & 1 & 6 \\
\hline Long & 9.36 & 1136 & 65 & 2 & 768 & 1 & 3 \\
\hline Mary & 0.68 & 810 & 11 & 0 & 968 & 1 & 2 \\
\hline Middle Osborn & 2.34 & 2361 & 240 & 2 & 1051 & 3 & 17 \\
\hline NW Molema & 1.06 & 610 & 154 & 2 & 881 & 1 & 6 \\
\hline $\begin{array}{l}\text { Sir Graham } \\
\text { Moore }\end{array}$ & 2.84 & 2746 & 61 & 1 & 979 & 1 & 34 \\
\hline St Andrew & 1.6 & 1470 & 284 & 2 & 1127 & 3 & 8 \\
\hline Storr & 0.26 & 1896 & 165 & 3 & 1007 & 3 & 11 \\
\hline Sunday & 8.06 & 1198 & 59 & 2 & 778 & 1 & 6 \\
\hline $\begin{array}{l}\text { South West } \\
\text { Osborn }\end{array}$ & 2.67 & 1339 & 134 & 3 & 1041 & 3 & 18 \\
\hline Un-named & 0.69 & 911 & 83 & 2 & 1000 & 2 & 13 \\
\hline Uwins & 0.23 & 3247 & 134 & 3 & 1155 & 2 & 11 \\
\hline Wargul Wargul & 0.25 & 634 & 87 & 1 & 946 & 3 & 7 \\
\hline Wulalam & 0.86 & 418 & 77 & 1 & 901 & 1 & 6 \\
\hline
\end{tabular}


annual rainfall, maximum elevation of an island and sampling effort. We also included two habitat descriptors: 'boulder' which represents the extent of rock scree on each island (i.e. refuge habitat) and 'rainforest' representing the extent of rainforest patches on each island. We defined island size as the area of land mass (ha) that was unlikely to be inundated (i.e. tidal mudflats and mangroves were excluded), and was determined from digitised 1:100,000 topographic maps. Maximum elevation (m) was extracted from the 1:100,000 topographic maps. Distance to the nearest larger landmass $(\mathrm{km})$ was estimated using Google Earth ${ }^{\mathrm{TM}}$ imagery. Average annual rainfall ( $\mathrm{mm})$ was derived using the BIOCLIM module of ANUCLIM (Houlder et al. 2000). Using ArcMap GIS (ESRI Inc., Redlands, California, USA), rainfall values were extracted for each site sampled on an island as well as either four (one-site islands) or six (two-site islands) additional random sites across the islands and averaged for each island. Pairwise Pearson correlations between all candidate variables revealed a strong inter-correlation between rainforest and rainfall $(P=0.80)$; the latter was retained in the analysis as rainforest was largely subjective and rainfall was considered more informative.

\section{DATA ANALYSIS}

\section{SPECIES RICHNESS}

The total number of camaenid species and genera, and non-camaenid species was calculated for each island and investigated for overall sampling adequacy by examining the observed (samplebased) species accumulation curves generated in the package PRIMER version 6 (Clarke and Gorley 2006).

The association between species/genus richness and all possible subsets of the six predictor variables (described above) was modelled using a generalised linear model (GLM), assuming a Poisson distribution. Island size and distance to the nearest larger landmass was log-transformed prior to analysis. Possible curvilinear relationships were first examined by preliminary inspection of response curves after fitting univariate generalised additive models (GAM) (see Wintle et al. 2005). As near-linear relationships were observed, the use of GLM was considered appropriate compared to techniques that fit more complex relationships. However, polynomial terms were included where required (i.e. according to inspection of the GAMs). Model selection was based on the second-order Akaike Information Criterion (AIC) (Burnham and Anderson 2002). There was no evidence of overdispersion (i.e. c-hat $>1$ ). We included models in a final candidate set for model averaging, where inference is based on a set of plausible models to estimate parameters. We also calculated AIC weights $\left(w_{i}\right)$ and used these to weight model coefficients. The relative importance of covariates was examined by summing the $\mathrm{AIC}_{c}$ weights for each covariate across all models in which it occurred $\left(w_{+} ;\right.$Burnham and Anderson 2002). Data analyses were run in the $\mathrm{R}$ statistical computing language ( $R$ Development Core Team 2009) and the 'AICcmodavg' package to calculate the $\mathrm{AIC}_{c}$ values and standard errors. We evaluated the performance of the model-averaged model by regressing the fitted values against observed species richness values.

\section{PATTERNS IN SPECIES COMPOSITION}

Compositional patterns of land snail communities across the islands were investigated using PRIMER version 6 (Clarke and Gorley 2006). Compositional similarity among all pairs of sites (based on presence/absence data) was computed using the zero-adjusted (Clarke et al. 2006) Sørensen association measure. Hierarchical clustering on the resulting similarity matrix was used to derive classification groups, coupled with a similarity profiled permutation test (SIMPROF) to identify genuine clusters in samples which are a priori unstructured (using default settings). The dimensionality of the similarity matrix was reduced using non-metric multi-dimensional scaling (nMDS; minimum stress of 0.005 and 100 restarts) and displayed as a scatter plot. To explore the relationship between compositional similarity and island attributes (explained above), we used the BEST/BIOENV procedure where the distances in the similarity matrix are rank-order matched with the Euclidean distances among each of the island attributes using Spearman's rank correlation and 99 permutations. This procedure calculates the Spearman's rank correlation coefficient (rho) using every possible combination of the predictor variables (island attributes here) until it finds the combination whose Euclidian distance matrix yields the highest value of rho (Geffen et al. 2004).

The degree of spatial structure (or distance decay) in the composition of the snail faunas was examined using Mantel's tests. A Euclidian distance matrix was calculated for geographical distance based on the geographical coordinates of the mid-points of the islands. The significance of the relationship between this matrix and the compositional similarity matrices (described above) were examined using 999 permutations. Partial Mantel tests were used to examine the relationship between compositional similarity and each of the environmental attributes (after calculating Euclidian distance matrices for each attribute), while holding the geographic distance matrix 


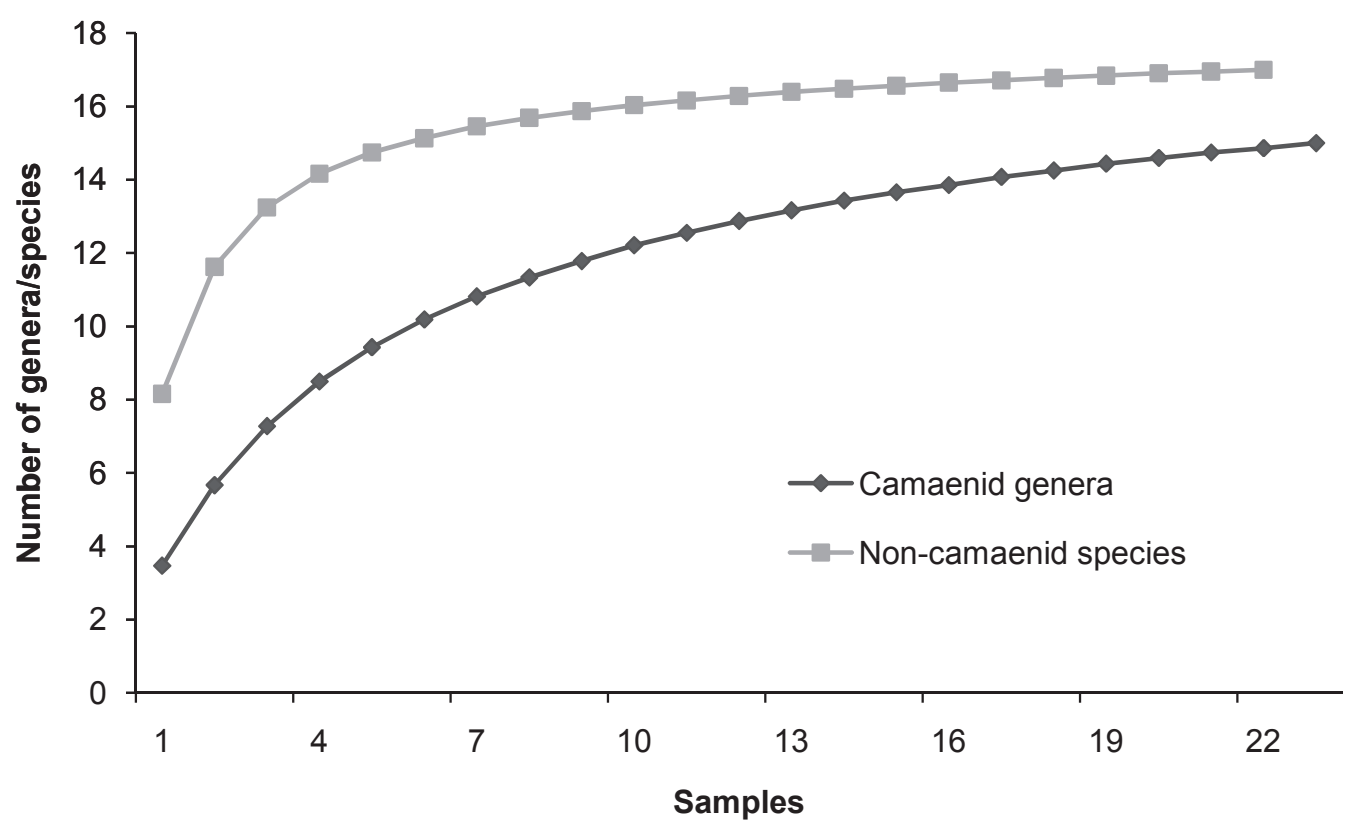

FIGURE 2 Observed (sample-based) species accumulation curves for the richness of camaenid land snail genera and non-camaenid species across the Kimberley islands sampled.

constant. All Mantel tests were performed using the program PASSaGE 2.0.11.6 (Rosenberg and Anderson 2011).

To examine co-occurrences of camaenid genera and non-camaenid species on the same islands we used the association measure 'Two-step' (Belbin 1980) in the analysis package PATN (Belbin 1995). Flexible UPGMA (unweighted pair-group mean averaging) (Sneath and Sokal 1973), with the clustering parameter (Beta) set to -0.1, was used to derive classification groups. The resulting association matrix was imported into PRIMER and displayed as nMDS ordination.

\section{RESULTS}

\section{CAMAENID LAND SNAILS}

On average $4.0 \pm 0.3$ (mean \pm standard error; range: 1-13) camaenid species and $3.4 \pm 0.4$ (range: 1-8) camaenid genera were recorded per island (Appendix 1, Table 2). The average number of islands where an individual species was recorded was $1.07 \pm 0.03$. In only four cases, the same species was recorded on two islands (Globorhagada wurroolgu, G. yoowadan, Rhagada cygna and Setabaudinia umbadayi) and one case where the same species (Xanthomelon obliquirugosa) was recorded on the three northern-most islands (Mary, Sir Graham Moore and Wargul Wargul). Islands with duplications were in close proximity to each other. In all other cases each species was unique to a single island. On large islands with two sampling sites, some species were recorded at only one of these localities, indicating that these species' ranges were actually smaller than the island. This almost complete turnover among islands resulted in a steeply rising species accumulation curve (SAC), indicating that each new island sampled is likely to contain unique species. We recorded a total of 89 camaenid species on the islands sampled, with 73 endemic to the islands. At the level of genus, the SAC reached an asymptote (Figure 2), indicating that all existing genera were well represented on the suite of islands sampled. We removed Byam Martin from the analysis as it was under-sampled in the dry season and was not sampled in the wet season.

An examination of the factors potentially influencing species richness of the camaenids on the islands revealed no clear best approximating model (i.e. $w_{\min } \geq 0.9$ ), and therefore the modelaveraging approach we used was appropriate (Burnham and Anderson 2002). In Table 3, the top eight models are ranked according to their AIC differences $\left(\Delta_{i}\right)$, from best to worst. Model-averaged coefficients, unconditional standard errors and 
TABLE 2 Camaenid land snail genera recorded on the islands sampled along the Kimberley coast. Total number of genera recorded on each island is also shown.

Abbreviations: AM - Amplirhagada, AU - Australocosmica, BA - Baudinella, CA - Carinotrachia, GL - Globorhagada, KD - Kimberleydiscus, KM - Kimberleymelon, KT - Kimberleytrachia, KB - Kimboraga, MO - Molema, RE - Retroterra, RG - Rhagada, SB - Setobaudinia, $\mathrm{TI}$ - Torresitrachia, XM - Xanthomelon.

\begin{tabular}{|c|c|c|c|c|c|c|c|c|c|c|c|c|c|c|c|c|}
\hline Island & AM & $A U$ & BA & $\mathrm{CA}$ & GL & $\mathrm{KD}$ & $\mathrm{KM}$ & KT & KB & MO & $\mathrm{RE}$ & RG & SB & $\mathrm{TI}$ & $\mathrm{XM}$ & Total \\
\hline Adolphus & $x$ & - & - & - & - & - & - & - & - & - & - & - & - & - & - & 1 \\
\hline Augustus & $x$ & $x$ & $x$ & - & $x$ & - & - & $x$ & - & - & - & $x$ & $x$ & $x$ & - & 8 \\
\hline Bigge & $x$ & - & - & - & $x$ & $x$ & - & $x$ & - & - & - & $x$ & $x$ & $x$ & - & 7 \\
\hline Boongaree & $x$ & - & $x$ & - & $x$ & - & - & $x$ & - & - & $x$ & $x$ & $x$ & $x$ & - & 8 \\
\hline Byam Martin & - & - & - & - & - & - & - & - & - & - & - & $x$ & - & $x$ & - & 2 \\
\hline Coronation & $x$ & $x$ & - & - & $x$ & - & - & - & $x$ & - & - & - & $x$ & - & - & 5 \\
\hline Hidden & - & - & - & - & - & - & - & - & - & - & - & $x$ & - & $x$ & - & 2 \\
\hline Jungulu & - & $x$ & $x$ & - & $x$ & - & - & $x$ & - & - & - & - & - & $x$ & - & 5 \\
\hline Katers & $x$ & - & - & - & $x$ & - & - & - & - & - & - & - & - & $x$ & - & 3 \\
\hline Kingfisher & $x$ & - & - & - & - & - & - & - & - & - & - & - & - & $x$ & - & 2 \\
\hline Lachlan & - & - & - & - & - & - & - & - & $x$ & - & - & - & - & - & - & 1 \\
\hline Long & - & - & - & - & - & - & - & - & - & - & - & $x$ & - & - & - & 1 \\
\hline Mary & - & - & - & - & - & - & - & - & - & - & - & - & - & - & $x$ & 1 \\
\hline Middle Osborn & $x$ & - & - & $X$ & - & - & $X$ & - & - & - & - & - & $x$ & - & - & 4 \\
\hline NW Molema & $\mathrm{X}$ & - & - & - & - & - & - & - & - & $x$ & - & - & $x$ & $x$ & - & 4 \\
\hline $\begin{array}{l}\text { Sir Graham } \\
\text { Moore }\end{array}$ & - & - & - & - & - & - & - & - & - & - & - & - & - & $x$ & $X$ & 2 \\
\hline St Andrew & $\mathrm{X}$ & - & - & - & - & - & - & - & $x$ & - & - & - & $x$ & - & - & 3 \\
\hline Storr & $x$ & - & - & - & $x$ & - & - & $x$ & - & - & - & $x$ & $x$ & $x$ & - & 6 \\
\hline Sunday & - & - & - & - & - & - & - & - & - & - & - & $x$ & - & - & - & 1 \\
\hline $\begin{array}{l}\text { South West } \\
\text { Osborn }\end{array}$ & $x$ & - & - & $X$ & - & - & - & - & - & - & - & - & $x$ & - & - & 3 \\
\hline Un-named & $X$ & - & - & - & $x$ & - & - & - & - & - & - & - & - & $x$ & - & 3 \\
\hline Uwins & $X$ & - & - & - & $x$ & - & - & $x$ & - & - & $x$ & - & - & - & - & 4 \\
\hline Wargul Wargul & $X$ & - & - & - & - & - & - & - & - & - & - & - & $x$ & - & $X$ & 3 \\
\hline Wulalam & - & - & - & - & - & - & - & - & $x$ & - & - & - & $x$ & - & - & 2 \\
\hline
\end{tabular}


TABLE 3 Results of $\mathrm{AlC}_{c}$-based model selection for the species richness of camaenid land snails on Kimberley islands (top eight most-supported models are shown; also shows maximised log-likelihood function $(\log (L))$, number of model parameters $(K), A C_{c}$ differences $\left(\Delta_{i}\right)$, Akaike weights $\left(W_{i}\right)$ and percent of deviance explained by each model (\%Dev).

* Model includes variables: rain - average annual rainfall; area - area of island; distance - distance from nearest larger land mass; elevation - maximum elevation; boulder - extent of rock scree.

\begin{tabular}{lllllll} 
Model $^{*}$ & $\log (\mathrm{L})$ & $K$ & $\mathrm{AIC}_{c}$ & $\Delta_{i}$ & $w_{i}$ & $\% \mathrm{DEV}$ \\
\hline rain + log(area) & -42.39 & 3 & 92.04 & 0.00 & 0.108 & 68.7 \\
rain + boulder & -42.52 & 3 & 92.31 & 0.27 & 0.095 & 68.2 \\
rain + $\log ($ area $)+$ elevation & -41.22 & 4 & 92.66 & 0.62 & 0.079 & 73.6 \\
rain & -44.14 & 2 & 92.88 & 0.83 & 0.071 & 61.4 \\
rain + elevation & -42.84 & 3 & 92.94 & 0.90 & 0.069 & 66.9 \\
rain + boulder + elevation & -41.45 & 4 & 93.12 & 1.08 & 0.063 & 72.7 \\
rain + log(area) $+\log ($ distance $)$ & -41.59 & 4 & 93.39 & 1.35 & 0.055 & 72.1 \\
rain + log(area) + boulder & -41.76 & 4 & 93.75 & 1.71 & 0.046 & 71.4 \\
\hline
\end{tabular}

the sum of weights for models containing each candidate variable are shown in Table 4. In terms of explaining variation in species richness across all the islands sampled, the model-averaged model performed well (Adjusted $R$-square $=0.70$, $P<0.0001)$. Species richness increased with rainfall, island area, maximum elevation and the extent of rock scree on an island. Rainfall was clearly the most strongly supported $\left(w_{+}=0.92\right)$ followed by area $\left(w_{+}=0.49\right)$, maximum elevation $\left(w_{+}=0.43\right)$ and boulder $\left(w_{+}=0.40\right)$. A positive relationship with the number of sites sampled on

TABLE 4 Model-averaged coefficients and unconditional standard errors for each variable in the camaenid analysis. Sum of weights for models containing each coefficient $w_{+}$are also shown.

Key: rain - average annual rainfall; area - area of island; elevation - maximum elevation; boulder - extent of rock scree; distance - distance from nearest larger landmass; sites - number of sites sampled on an island.

\begin{tabular}{llll} 
Variable & Coefficient & Standard Error & $W_{+}$ \\
\hline Intercept & -3.320 & 1.184 & - \\
rain & 0.003 & 0.002 & 0.92 \\
$\log ($ area $)$ & 0.266 & 0.354 & 0.49 \\
elevation & 0.001 & 0.002 & 0.43 \\
boulder & 0.105 & 0.174 & 0.40 \\
$\log ($ distance) & -0.061 & 0.159 & 0.26 \\
sites & 0.003 & 0.011 & 0.22 \\
\hline
\end{tabular}




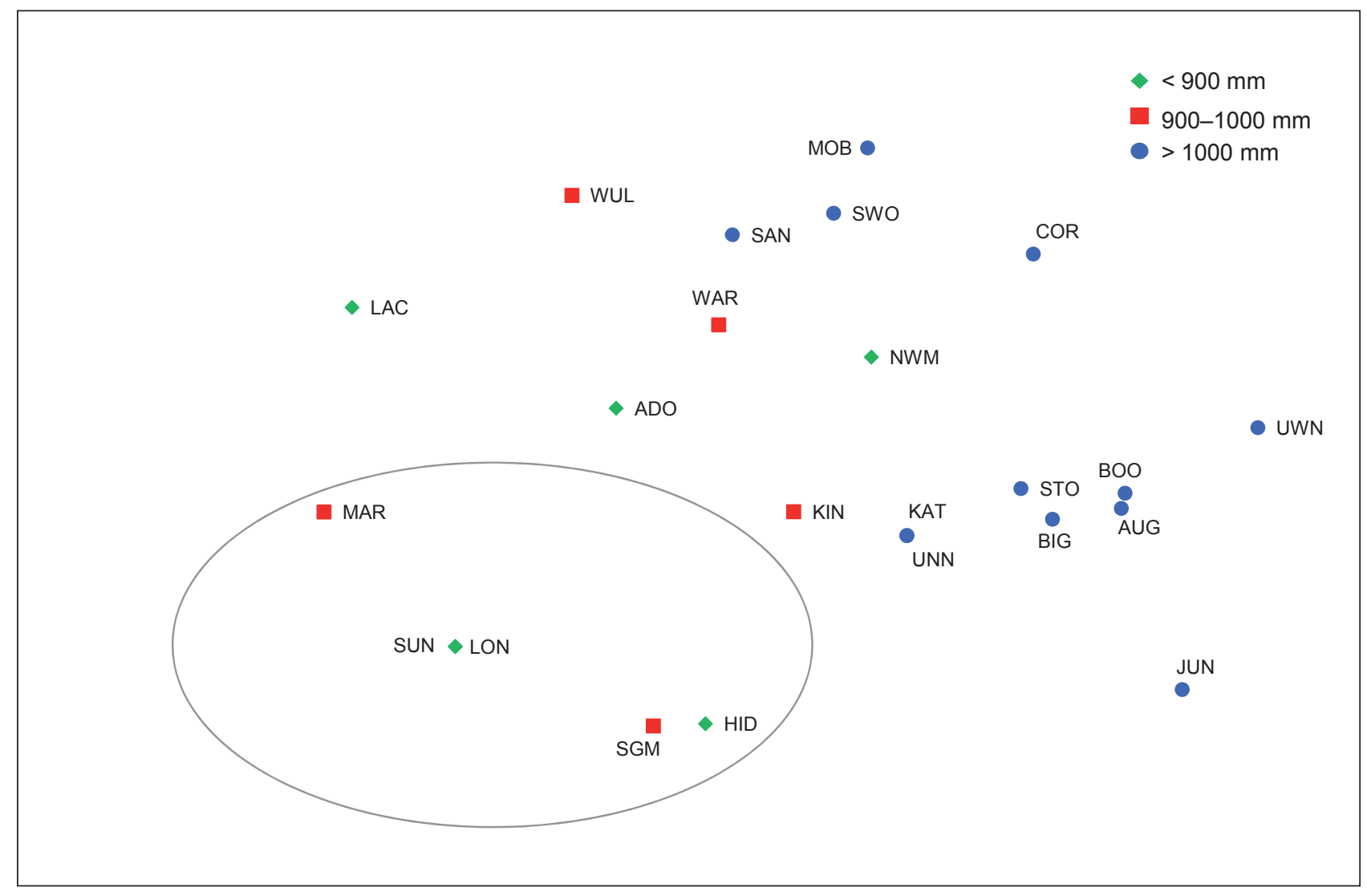

FIGURE 3

\begin{abstract}
Non-metric MDS plot of compositional patterns of camaenid land snail communities (genera) across the Kimberley islands sampled, based on zero-adjusted Sørensen similarity matrix (2D stress $=0.14$ ). Three rainfall bands (low, moderate and high) are indicated by dot shape and colour on the plot. SIMPROF clusters are indicated (i.e. points either within or outside the ellipse).

Key: ADO - Adolphus, AUG - Augustus, BIG - Bigge, BOO - Boongaree, COR - Coronation, JUN - Jungulu, HID - Hidden, KAT - Katers, KIN - Kingfisher, LAC - Lachlan, LON - Long, MAR - Mary, MOB - Middle Osborn, NWM - NW Molema, SGM - Sir Graham Moore, SAN - St Andrew, STO - Storr, SUN - Sunday, SWO - South West Osborn, UNN - Un-named, UWN - Uwins, WAR - Wargul Wargul, WUL - Wulalam. Note that SUN and LON, and KAT and UNN are coincident on the plot.
\end{abstract}

an island and a negative relationship with distance from the nearest larger land mass was also observed, but these variables had relatively weak support $\left(w_{+}<0.3\right)$. All of the eight most-supported models explained at least $61 \%$ of the deviance (range: 61-74\%) with the model that contained rainfall on its own explaining $61.4 \%$.

Due to the exceptionally high turnover of camaenid species among islands, we examined the compositional patterns at the level of the genus (Köhler 2011b). The most widespread genus was Amplirhagada, detected on over half of the islands sampled (15), closely followed by Torresitrachia (12 islands) and Setobaudinia (11 islands) (Table 2). When the islands were re-ordered according to similarities in their composition of genera, two main groups became apparent (Figure 3). Hidden,
Long, Sunday, Mary and Sir Graham Moore were clustered into one group and the remaining islands into another. All the islands in the first group have a relatively low annual rainfall $(<1,000 \mathrm{~mm})$ and, with the exception of Hidden, they were devoid of extensive rock scree and were amongst the lowest of the islands in terms of elevation. The maximum number of genera on any one of these islands was two. The majority of islands in the remaining group received an annual rainfall of greater than $1,000 \mathrm{~mm}$, and includes islands with extensive rock scree and high in maximum altitude. With a few exceptions (e.g. Katers and St Andrew), the diversity of genera on these islands was much higher with a maximum of eight. Examining the role of individual genera in contributing to the separation between the two groups (using SIMPER 


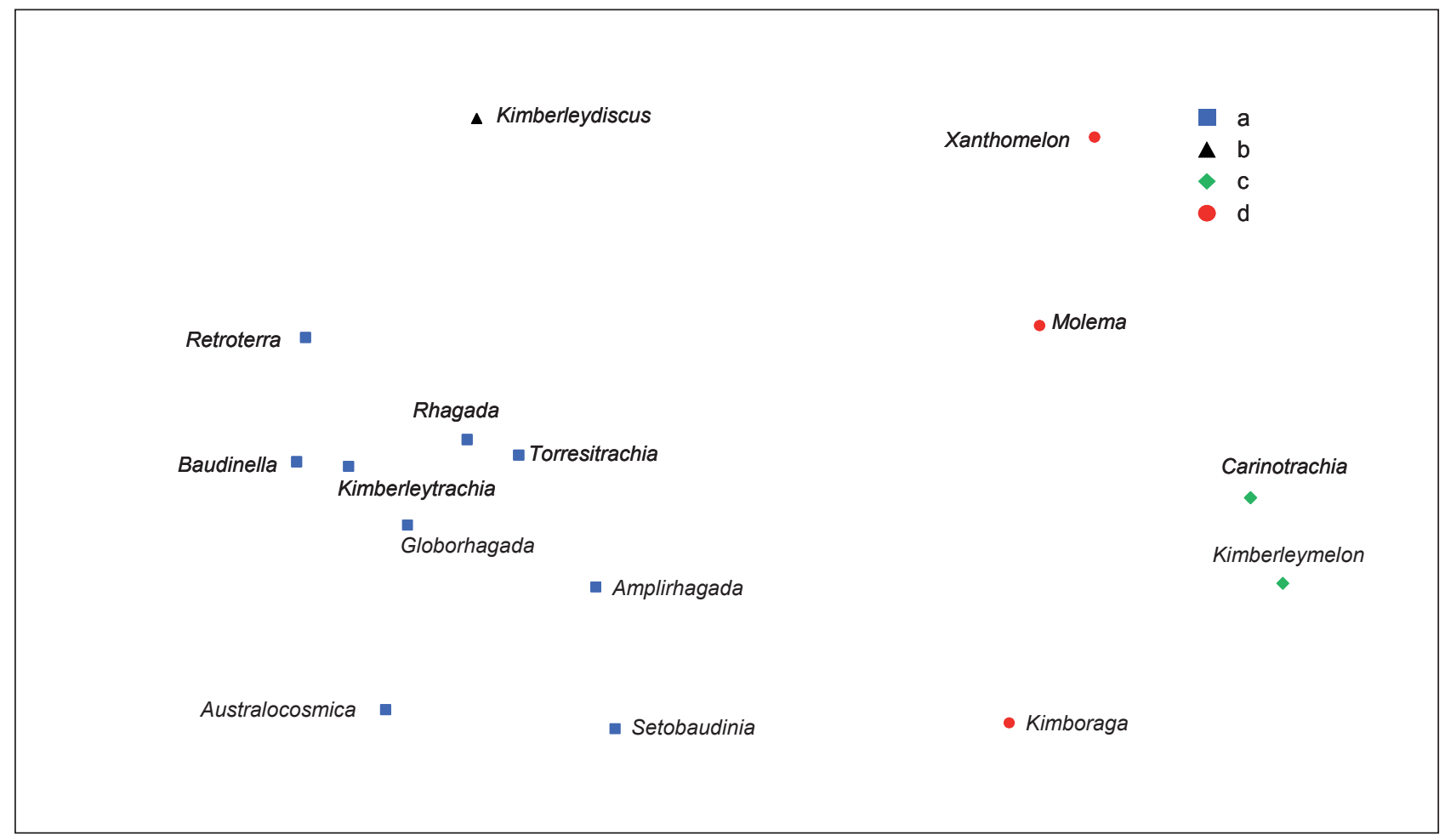

FIGURE $4 \quad$ Non-metric MDS plot of camaenid genera according to their co-occurrences on the Kimberley islands, based on the Two-step association measure (2D stress $=0.06)$. UPGMA classification clusters $(a, b, c$, d) are indicated by dot shape and colour on the plot.

in PRIMER) showed that Amplirhagada, Rhagada, Setobaudinia and Torresitrachia contributed to over half $(56.7 \%)$ of the average dissimilarity between groups. In coastal areas, species of Amplirhagada and Setobaudinia are restricted to rainforest habitats, whereas Rhagada are known to occur in a variety of habitats including semi-arid areas (Solem and McKenzie 1991; Köhler 2010a). The BIOENV procedure indicated that of the six attributes considered, a combination of average annual rainfall and the extent of rock scree on an island had the strongest association with compositional similarity (Spearman's rho $=0.52$ ). The strongest relationship between compositional similarity and any single variable was rainfall (Spearman's rho $=0.41$ ), indicating that the added influence of rock scree was marginal. Overlaying three rainfall bands $(<900,900-1,000$ and $>1,000 \mathrm{~mm})$ on the nMDS plot also revealed an overt rainfall gradient (Figure 3). The remaining variables such as island area, distance to a larger landmass and sampling effort contributed little to explaining the compositional patterns observed.

Species similarity among islands did not decrease significantly with geographical distance (Mantel $\mathrm{r}$ $=0.234, P=0.05)$, genus similarity among islands however did (Mantel $r=-0.262, P<0.01$ ). When we corrected for the effect of geographical distance, the correlation of genus similarity with both rainfall and extent of rock scree (expressed as distance matrices) remained significant (Mantel $\mathrm{r}=-0.371, P$ $<0.01$ and Mantel $\mathrm{r}=-0.300, P<0.01$, respectively).

When we examined genera according to their co-occurrences on the same island, four groups emerged (Figure 4). Group 'a' comprises nine genera, which includes the widespread Amplirhagada, Torresitrachia, Setobaudinia, Rhagada and Globorhagada that are known to occur through high to medium rainfall areas of the Kimberley region (Solem 1981a, 1985, 1991, 1997; Köhler 2011b). At least two of the remaining genera (Baudinella and Retroterra) in this group are known to be confined to the high rainfall area of the Kimberley (Solem 1985, 1991; Köhler 2011b). The other two are new genera (Australocosmica and Kimberleytrachia) (Köhler 2011a, 2011b) but also appear to be restricted to higher rainfall areas (islands where they occurred have an annual rainfall greater than 1000 $\mathrm{mm}$ ). Group ' $\mathrm{b}$ ' consists of Kimberleydiscus, a newly described monotypic genus recorded only from Bigge. Group ' $\mathrm{C}$ ' contains two genera Carinotrachia and Kimberleymelon confined to Middle Osborn and South West Osborn. Carinotrachia has a highly restricted distribution occurring only in the wettest parts of the Kimberley region (Solem 1985; Köhler 2011b). Kimberleymelon is a new monotypic genus 


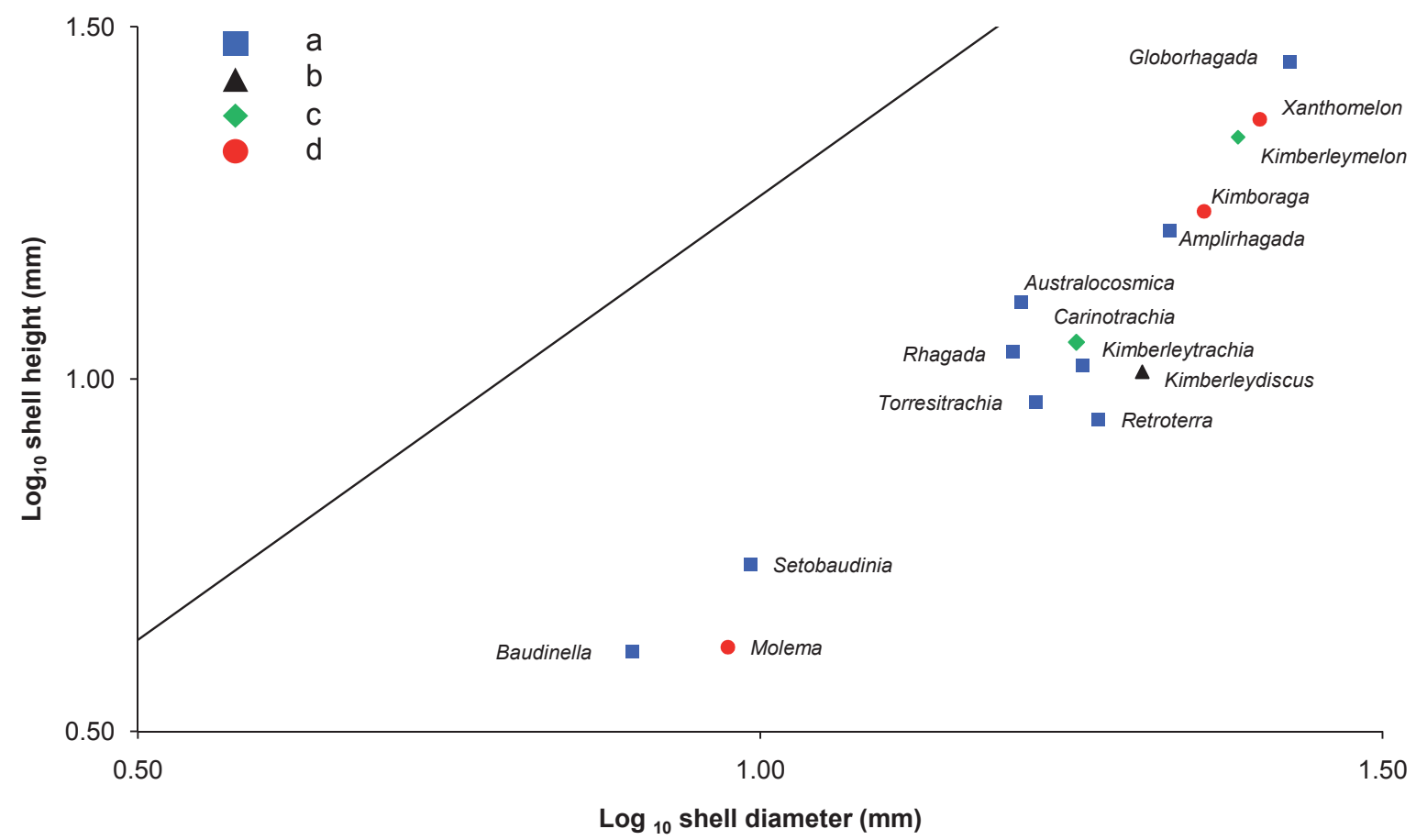

FIGURE 5 Average shell spire dimensions (height/diameter) of each of the camaenid genera across all of the islands sampled. UPGMA classification clusters (a, b, c, d) are indicated by dot shape and colour on the plot. Diagonal line indicates where height equals diameter.

known only from Middle Osborn (Köhler 2011b). Molema, Kimboraga and Xanthomelon form group 'd'. The latter two are known to extend into the driest parts of the Kimberley (Solem 1985; Köhler 2011b). Molema is a new genus (Köhler 2011b), which was recorded on NW Molema only (an island with an average rainfall of less than $900 \mathrm{~mm}$ ). Xanthomelon was recorded only on the three northern-most islands.

We superimposed the groups above on a plot showing average shell height $\mathrm{v}$. shell diameter for each genus (Figure 5). Co-occurring genera tended to be well separated along the height/ width gradient indicating clear differences in shell shape. Five genera within the first group are similar in shape, but with the exception of Torresitrachia and Rhagada, they are from different sub-groups within the main cluster, implying less frequent cooccurrences.

\section{NON-CAMAENID LAND SNAILS}

The non-camaenid land snail fauna detected on the islands consisted of terrestrial and aquatic species. Freshwater snails were more restricted in their occurrence due to the scarcity of permanent freshwater on the islands, with only four species detected (Kohler et al. 2012). Consequently, we consider only the terrestrial non-camaenid species in further analyses. The 17 species detected during the survey represent $75 \%$ of all terrestrial, noncamaenid gastropods known from the entire Kimberley region (Solem 1991). We again removed Byam Martin from the analysis due to undersampling.

The mean number of non-camaenid land snail species recorded per island was twice as high as the camaenids at $8.23 \pm 0.91$ (range: 1-15) (Table $5)$. The average number of islands where an individual species was recorded was $10.65 \pm 1.15$ (range: 1-19). The most widespread species were Gastrocopta macdonnelli and Westracystis lissus which were detected on 19 and 18 islands, respectively. One species was endemic to the islands, the new 'Assimineid n. gen. n. sp.', found on Middle Osborn only. The SAC curve reached an asymptote (Figure 2) indicating that, overall, non-camaenid species were sufficiently sampled across the islands surveyed.

As for the camaenids, there was no clear best approximating model (i.e. $w_{\min } \geq 0.9$ ) in terms of explaining variation in species richness across all the islands sampled. However, only two models were strongly supported (i.e. Akaike differences $<2$ ) and both had in common the attribute of rainfall. The number of locations sampled on 
TABLE 5 Terrestrial non-camaenid land snail species recorded on islands sampled along the Kimberley coast. Total number of species recorded on each island is also shown.

Abbreviations: Am - Amimopina macleayi, As - Assimineid n. gen., n. sp.,

$\mathrm{Cm}$ - Coneuplecta microconus, Da - Discocharopa aperta, Ei - Eremopeas interioris,

Gk - Gastrocopta kessneri, Gm - Gastrocopta macdonnelli, Gp - Gastrocopta pediculus,

Gs - Gastrocopta stupefacians, Nm - Nesopupa mooreana, Pw - Pleuropoma walkeri,

Pc - Pupisoma circumlitum, Po - Pupisoma orcula, Pp - Pupoides pacificus,

Sc - Stenopylis coarctata, WI - Westracystis lissus, Wm - Wilhelminaia mathildae.

\begin{tabular}{|c|c|c|c|c|c|c|c|c|c|c|c|c|c|c|c|c|c|c|}
\hline Island & $\mathrm{Am}$ & As & $\mathrm{Cm}$ & $\mathrm{Da}$ & $\mathrm{Ei}$ & Gk & $\mathrm{Gm}$ & $\mathrm{Gp}$ & Gs & $\mathrm{Nm}$ & Pw & $\mathrm{Pc}$ & Po & $\mathrm{Pp}$ & Sc & WI & $\mathrm{Wm}$ & Total \\
\hline Adolphus & - & - & - & - & - & - & - & $x$ & - & - & - & - & - & $x$ & - & $X$ & - & 3 \\
\hline Augustus & $X$ & - & - & $x$ & $X$ & $x$ & $x$ & - & $x$ & $x$ & $x$ & $x$ & - & - & $x$ & $X$ & - & 11 \\
\hline Bigge & $x$ & - & - & - & $x$ & $x$ & $x$ & $x$ & $x$ & $x$ & $x$ & - & $x$ & $x$ & $x$ & $x$ & - & 12 \\
\hline Boongaree & $x$ & - & $x$ & $x$ & $x$ & $x$ & $x$ & - & $x$ & $x$ & $x$ & $x$ & $x$ & $x$ & $x$ & $x$ & $x$ & 15 \\
\hline Byam Martin & - & - & - & - & $x$ & - & - & - & $x$ & - & - & - & - & - & $x$ & $x$ & - & 4 \\
\hline Coronation & $x$ & - & - & $x$ & $x$ & $x$ & $x$ & $x$ & $x$ & $x$ & $x$ & $x$ & $x$ & $x$ & $x$ & $x$ & $X$ & 15 \\
\hline Hidden & - & - & - & - & - & - & $x$ & - & - & - & - & - & - & - & - & - & - & 1 \\
\hline Jungulu & $x$ & - & - & - & - & $x$ & $x$ & - & $x$ & $x$ & $x$ & $x$ & $x$ & $x$ & $x$ & $x$ & - & 11 \\
\hline Katers & - & - & - & - & - & $x$ & $x$ & - & $x$ & $x$ & $x$ & - & $x$ & $x$ & $x$ & $x$ & - & 9 \\
\hline Kingfisher & - & - & - & $x$ & $x$ & - & $x$ & - & - & $x$ & $x$ & - & - & - & $x$ & $x$ & - & 7 \\
\hline Lachlan & - & - & - & - & $x$ & - & $x$ & - & - & $x$ & - & - & - & $x$ & - & - & - & 4 \\
\hline Long & - & - & - & - & $X$ & - & $x$ & - & - & - & - & - & - & - & $x$ & - & - & 3 \\
\hline Mary & - & - & - & - & - & - & $x$ & $x$ & - & $x$ & - & - & - & $x$ & - & - & - & 4 \\
\hline Middle Osborn & $x$ & $x$ & $X$ & - & $X$ & $x$ & $x$ & - & $x$ & $x$ & $x$ & $x$ & $x$ & $x$ & $x$ & $x$ & - & 14 \\
\hline NW Molema & - & - & - & - & - & - & - & - & - & - & - & - & - & - & - & - & - & 0 \\
\hline $\begin{array}{l}\text { Sir Graham } \\
\text { Moore }\end{array}$ & - & - & - & - & - & $x$ & $x$ & $x$ & $x$ & $x$ & - & $x$ & - & $x$ & - & $x$ & - & 8 \\
\hline St Andrew & $x$ & - & - & $x$ & $x$ & $x$ & $x$ & - & $x$ & $x$ & $x$ & - & $x$ & - & $x$ & $x$ & - & 11 \\
\hline Storr & $x$ & - & - & $x$ & $x$ & $x$ & $x$ & - & - & - & $x$ & $x$ & - & $x$ & $x$ & $x$ & $x$ & 11 \\
\hline Sunday & - & - & - & - & $x$ & - & $x$ & - & - & - & - & - & - & - & - & $x$ & - & 3 \\
\hline $\begin{array}{l}\text { South West } \\
\text { Osborn }\end{array}$ & $X$ & - & - & $x$ & $X$ & $x$ & $x$ & - & $x$ & $x$ & $x$ & $x$ & $x$ & $x$ & $x$ & $x$ & - & 13 \\
\hline Un-named & - & - & - & - & $X$ & - & $x$ & - & - & $x$ & - & - & - & - & $x$ & $x$ & - & 5 \\
\hline Uwins & $x$ & - & - & - & $X$ & $x$ & $x$ & - & $x$ & $x$ & $x$ & - & $x$ & - & $x$ & $x$ & - & 10 \\
\hline Wargul Wargul & $x$ & - & - & - & $X$ & $x$ & - & - & $x$ & - & $x$ & - & - & - & $x$ & $x$ & - & 7 \\
\hline Wulalam & - & - & - & - & - & - & - & - & $x$ & $x$ & - & - & $x$ & - & - & $x$ & - & 4 \\
\hline
\end{tabular}


TABLE 6 Results of $\mathrm{AlC}_{c}$-based model selection for the species richness of non-camaenid land snails on Kimberley islands (the 10 most-supported models are shown). Also shown are maximised loglikelihood function (log $[L])$, number of model parameters $(K), A I C_{c}$ differences $\left(\Delta_{i}\right)$, Akaike weights $\left(w_{i}\right)$ and percent of deviance explained by each model (\%Dev).

"Model includes variables: rain - average annual rainfall $(\mathrm{mm})$; sites - number of sites sampled; sites2 - sites squared; area - area of island (ha); boulder - extent of rock scree; distance - distance from nearest larger landmass $(\mathrm{km})$; elevation - maximum elevation $(\mathrm{m})$.

\begin{tabular}{lllllll} 
Model* $^{*}$ & $\log (\mathrm{L})$ & $K$ & $\mathrm{AIC}_{c}$ & $\Delta_{i}$ & $W_{i}$ & $\% \mathrm{DEV}$ \\
\hline rain & -53.72 & 2 & 112.03 & 0.00 & 0.18 & 65.3 \\
rain + sites + sites2 & -51.00 & 4 & 112.21 & 0.18 & 0.16 & 73.2 \\
rain + elevation & -53.41 & 3 & 114.08 & 2.05 & 0.06 & 66.2 \\
rain + sites + sites2 + log(area) & -50.31 & 5 & 114.15 & 2.12 & 0.06 & 75.2 \\
rain + sites + sites2 + boulder & -50.34 & 5 & 114.22 & 2.18 & 0.06 & 75.1 \\
rain + log(distance) & -53.58 & 3 & 114.43 & 2.40 & 0.05 & 65.7 \\
rain + log(area) & -53.69 & 3 & 114.64 & 2.61 & 0.05 & 65.4 \\
rain + sites + sites2 + elevation & -50.58 & 5 & 114.68 & 2.65 & 0.05 & 74.4 \\
rain + boulder & -53.71 & 3 & 114.69 & 2.66 & 0.05 & 65.4 \\
rain + sites + sites2 + log(distance) & -50.91 & 5 & 115.34 & 3.31 & 0.03 & 73.4 \\
\hline
\end{tabular}

TABLE 7 Model-averaged coefficients and unconditional standard errors for each variable for the non camaenid analysis. Sum of weights for models containing each coefficient $w_{+}$are also shown.

Key: rain - average annual rainfall $(\mathrm{mm})$; sites - number of sites sampled on an island; sites2 - sites squared; elevation - maximum elevation (m); area - area of island (ha): boulder - extent of rock scree; distance - distance from nearest larger landmass (km).

\begin{tabular}{llll} 
Variable & Coefficient & Standard Error & $W_{+}$ \\
\hline Intercept & -1.662 & 1.050 & - \\
rain & 0.003 & 0.001 & 0.93 \\
sites & 0.061 & 0.075 & 0.52 \\
sites2 & -0.001 & 0.002 & - \\
elevation & 0.0003 & 0.0008 & 0.24 \\
log(area) & -0.035 & 0.133 & 0.22 \\
boulder & -0.019 & 0.079 & 0.21 \\
$\log ($ distance) & -0.0003 & 0.081 & 0.19 \\
\hline
\end{tabular}




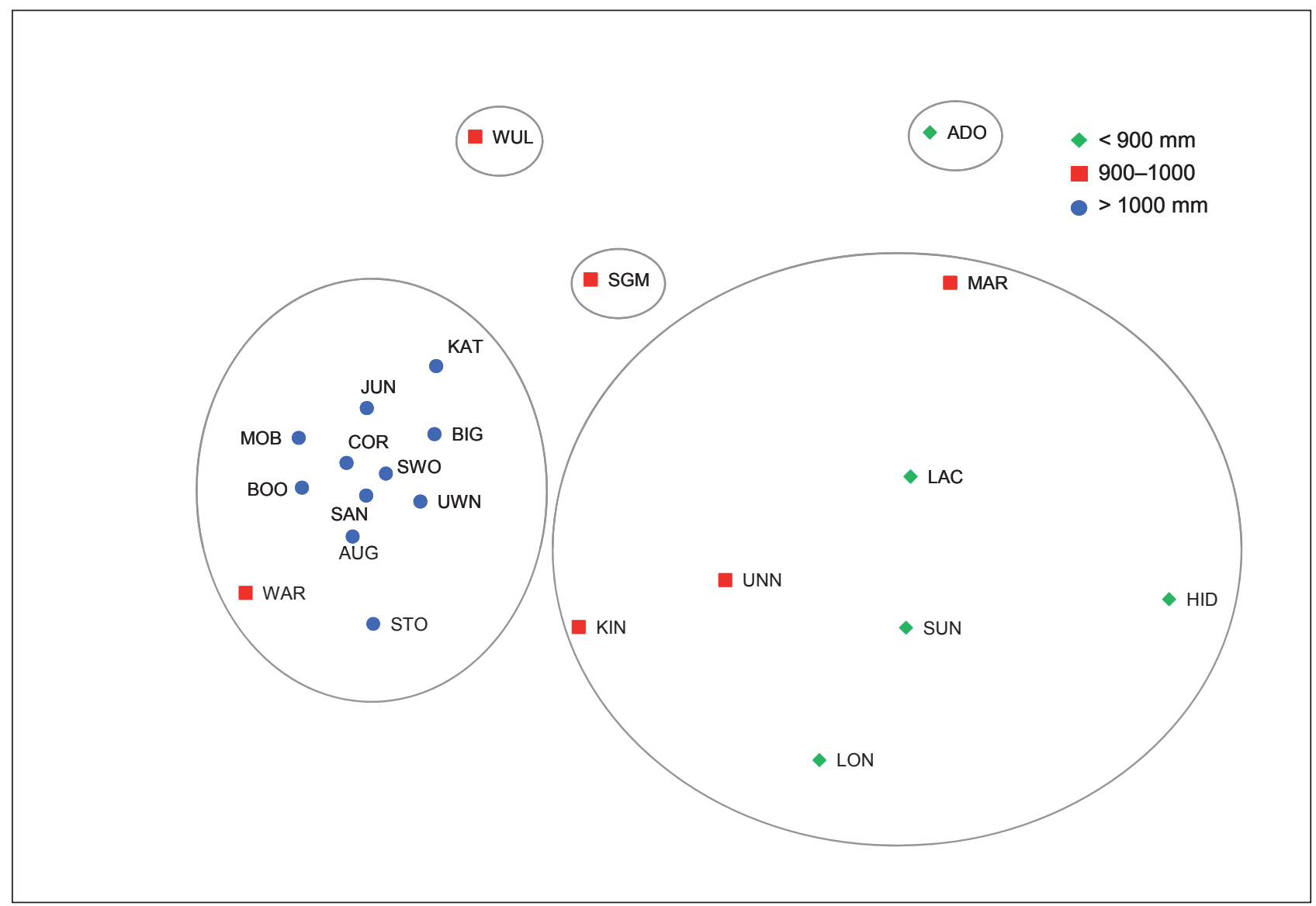

FIGURE 6

Non-metric MDS plot of compositional patterns of non-camaenid land snail communities (species) across the Kimberley islands sampled based on zero-adjusted Sørensen similarity matrix (2D stress = 0.10). Three rainfall bands (low, moderate and high) are indicated by dot shape and colour on the plot. SIMPROF clusters are indicated by the ellipses.

Key: ADO - Adolphus, AUG - Augustus, BIG - Bigge, BOO - Boongaree, COR - Coronation, JUN Jungulu, HID - Hidden, KAT - Katers, KIN - Kingfisher, LAC - Lachlan, LON - Long, MAR - Mary, MOB - Middle Osborn, SGM - Sir Graham Moore, SAN - St Andrew, STO - Storr, SUN - Sunday, SWO - South West Osborn, UNN - Un-named, UWN - Uwins, WAR - Wargul Wargul, WUL - Wulalam Island.

an island (or sampling effort) was included in the second-ranked model (Table 6). As shown in Table 7, species richness of the non-camaenids was strongly influenced only by rainfall $\left(w_{+}=0.93\right)$, with moderate support for sampling effort $\left(w_{+}=0.52\right)$. The importance of all other attributes was relatively weak $\left(w_{+}<0.3\right)$. Species richness increased with rainfall, sampling effort (to a threshold level) and maximum elevation, and decreased with extent of rock scree, island area and distance from a larger land mass (Table 5). The performance of the modelaveraged model was high (Adjusted $R$-square $=0.78, P<0.0001)$. All of the 10 most-supported models explained at least $65 \%$ of the deviance (range: $65-75 \%$ ) with the model including only rainfall explaining $65.3 \%$.
As no non-camaenid species were recorded on NW Molema, we removed this island from the compositional analysis. When we examined the islands according to similarities in their species composition, five groups emerged (Figure 6). Three groups consisted of only one island (Adolphus, Wulalam and Sir Graham Moore). The small number of species on both Adolphus and Wulalam may be an artifact of sampling effort. The main distinction between the two remaining groups appeared to be species diversity with one group (blue dots in Figure 6) containing islands with a higher number of co-occurring species. These islands are also located in the high rainfall zone (> $1,000 \mathrm{~mm}$ ), with the exception of Wargul Wargul $(946 \mathrm{~mm})$. Examining the role of individual species in contributing to the separation between these 

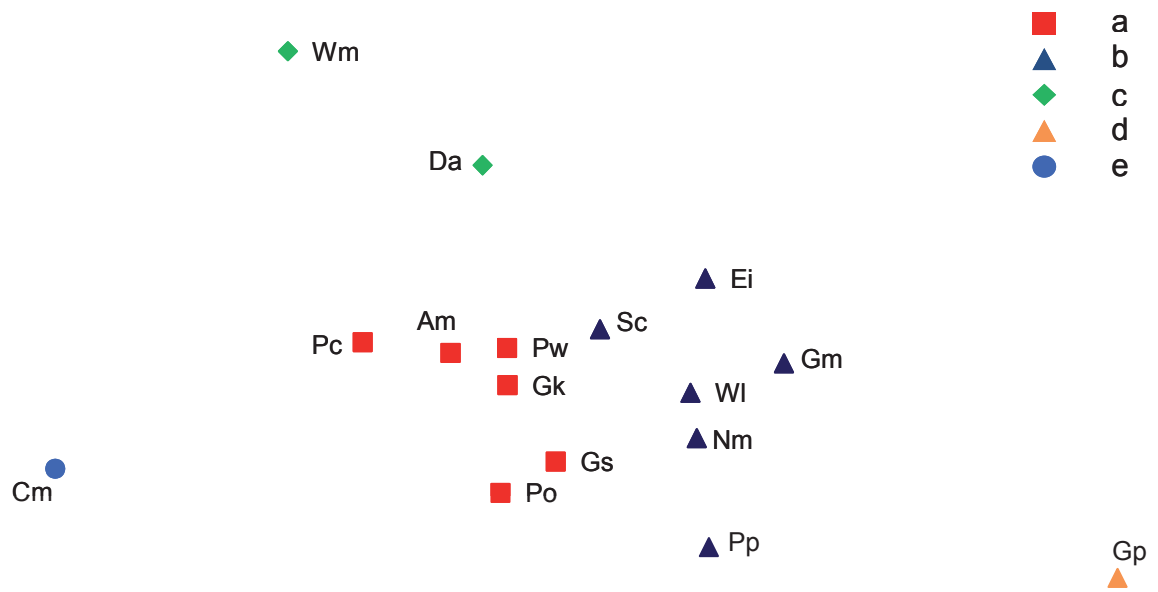

FIGURE $7 \quad$ Non-metric MDS plot of non-camaenid species according to their co-occurrences on the Kimberley islands based on the Two-step association measure (2D stress $=0.05$ ). UPGMA classification clusters are indicated by dot shape and colour on the plot.

Key: Pw - Pleuropoma walkeri, As - Assimineid n. gen., n. sp., Po - Pupisoma orcula, Pc - Pupisoma circumlitum, Nm - Nesopupa mooreana, Gp - Gastrocopta pediculus,

Gs - Gastrocopta stupefacians, Gm - Gastrocopta macdonnelli, Gk - Gastrocopta kessneri,

Pp - Pupoides pacificus, Am - Amimopina macleayi, Ei - Eremopeas interioris,

$\mathrm{Da}$ - Discocharopa aperta, Sc - Stenopylis coarctata, Cm - Coneuplecta microconus,

$\mathrm{WI}$ - Westracystis lissus, Wm - Wilhelminaia mathildae.

two main groups showed that Gastrocopta kessneri, G. stupefacians, Aminopina macleayi, Pleuropoma walkeri and Pupisoma orcula contributed to $50.1 \%$ of the average dissimilarity between the groups. All of these species are known to be more common in areas of high rainfall (Solem and McKenzie 1991). Of the combinations of the six attributes considered, the BIOENV procedure found that rainfall on its own had the strongest relationship with compositional similarity of the islands (Spearman's rho $=0.50)$. A rainfall gradient was also evident in the nMDS ordination plot, with the highrainfall islands tightly clustered and distant from the other islands (Figure 6). The remaining islands had an average annual rainfall of less than 1,000 $\mathrm{mm}$, except for Un-named $(\sim 1,000 \mathrm{~mm})$. Adding additional attributes only reduced the correlation, indicating they added little to explaining the compositional patterns.

Species similarity of the non-camaenids among islands decreased significantly with geographical distance (Mantel $\mathrm{r}=-0.521, P<0.01$ ). When we corrected for the effect of geographical distance, the correlation of species similarity with rainfall remained significant (Mantel $\mathrm{r}=-0.404, P<0.01$ ).

An examination of species based on their cooccurrences on the same island revealed five main groups (Figure 7). The species in group ' $a$ ' are known to occur in the high rainfall rainforests of the Kimberley and the Northern Territory (Solem 1988b, 1991; Pokryszko 1996; Solem and McKenzie 1991; Köhler et al. 2012). Group 'b' includes the more widespread species. Most have been recorded in a 
variety of habitats (including semi-arid areas) in the Kimberley, Northern Territory, New South Wales and Queensland (Solem 1988b, 1991; Pokryszko 1996; Stanisic et al. 2010; Köhler et al. 2012). Group 'c' contains two species (Discocharopa aperta and Wilhelminaia mathildae), which were recorded on relatively few islands. Discocharopa aperta appears to tolerate drier areas, extending into the arid zone of central Australia (Solem 1988b) whereas Wilhelminaia mathildae occurs mainly in the high rainfall rainforests of the Kimberley and Northern Territory (Solem 1988b; Köhler et al. 2012). It is also distributed from coastal southern New South Wales to northern Queensland (Stanisic et al. 2010; Köhler et al. 2012). Gastrocopta pediculus forms group ' $d$ ', occurring on only five islands, all located in the northern section of those sampled. This species is common in semi-arid areas of the Kimberley and Northern Territory (Solem 1991; Pokryszko 1996; Köhler et al. 2012). The final group ' $\mathrm{e}$ ' consists of two species, one newly discovered ('Assimineid n. gen. n. sp.') occurring only on Middle Osborn Island and Coneuplecta microconus, occurring on Middle Osborn and Boongaree. Both these islands contain volcanic substrates. Coneuplecta microconus is restricted to rainforests in the wetter areas of the Kimberley, Northern Territory and Queensland (Solem 1991; Stanisic et al. 2010; Köhler et al. 2012).

\section{DISCUSSION}

\section{CAMAENID LAND SNAILS}

\section{CORRELATES OF SPECIES RICHNESS}

Some studies have indicated that species richness is largely a function of sampling effort (e.g. Cowie 1995; Stanisic et al. 2007). In our case, sampling effort, as estimated by the number of locations sampled for land snails on an island, had a low contribution to explaining species richness, suggesting that the number of camaenid species recorded on an island was not biased by sampling effort.

Species richness on islands is a function of both colonisation and extinction events, as well as within-island speciation (Losos and Ricklefs 2009, 2010). Geographical and ecological factors such as island area, insularity, island age, elevation, habitat availability and diversity, as well as intrinsic factors such as dispersal capability and ecological tolerance are likely to influence the relative importance of these processes (Parent and Crespi 2006). On the continental islands along the Kimberley coast, we found that the richness of camaenid land snail species was strongly influenced by a rainfall gradient, with richness increasing with rising average annual rainfall. In this case, rainfall is likely to be a surrogate of habitat availability and structure. Rainfall was highly correlated with the extent of rainforest on an island. Rainforests are considered to be the best habitat for most camaenid land snail species as they provide a moist and protective environment suitable for these desiccation-prone organisms (Solem 1991). Solem and McKenzie (1991) similarly found that species richness of camaenids was related to rainfall over a broader area of the Kimberley. The number of camaenid species was also higher on larger islands, those with a higher elevation and a larger extent of rock scree. All these variables are indirect/ direct measures of habitat complexity or niche space (Cowie 1995; Parent and Crespi 2006). Larger and higher islands typically contain a greater range of potential habitats, which promotes higher speciation rates (Losos and Schluter 2000; Losos and Ricklefs 2009).

Rocky habitat is often associated with land snail occurrence (Solem and McKenzie 1991; Slatyer et al. 2007; Stanisic et al. 2007). Not only does it provide shelter, particularly for aestivating land snails, but it also provides protection from fire, a prominent feature in the Kimberley landscape. The high complexity of the rock scree habitat in the Kimberley also creates a diversity of niche space. Exposed, layered, rocks provide stable microclimatic conditions as they are cool, moist and relatively buffered from short- and longterm climatic changes. Couper and Hoskin (2008) suggested that rock habitats act as 'litho-refugia' for the persistence of a number of primary rainforest faunal groups in areas where once more widespread rainforest is marginal or absent. A similar evolutionary importance of rocky habitats can also be postulated for the Camaenidae.

The degree of habitat isolation can be deterministic in terms of species diversification. There is less chance of gene flow between areas of isolated habitat due to lower opportunities for colonisation (Losos and Ricklefs 2009). In the case of the camaenids, we found that distance of an island to a larger landmass (i.e. potential source of colonisation) was of little importance in determining species richness. This may indicate that species richness of the camaenids is not a function of colonisation/extinction dynamics, but is largely a function of in situ speciation. The limited dispersal ability of most camaenid land snails (Solem and McKenzie 1991; Cameron 1992) lends weight to this argument. As does that we found little evidence of species similarity among islands decreasing with geographical distance (see below). Dispersal capacity of land snails has been shown to be correlated with body size (e.g. Hausdorf 2000). Specifically, passive dispersal capacity tends to decrease with increasing body 
size (Hausdorf 2000). The camaenid land snails are relatively large compared to the non-camaenid families and they have certain anatomical features that increase their susceptibility to desiccation and lower their chances of passive dispersal (Solem and McKenzie 1991). A study by Johnson et al. (2010), focusing on Amplirhagada species from just parts of the Bonaparte Archipelago in the Kimberley, found that these island populations show little evidence of gene flow, despite periodic connections among islands and only small distances separating them. One possible explanation is that, much like on the mainland, camaenid species are restricted to habitat patches (such as rainforests) on the islands themselves, and if these habitats remain disjunct even when connected to the mainland or other islands, then gene flow is less likely (Johnson et al. 2010; Köhler 2010b). Such restricted gene flow is likely to encourage allopatric differentiation among islands and in situ speciation within islands. When we treated the two campsites on the larger islands separately, we found some evidence of dispersal across an island. The campsites on the same island were more similar to each other than any other campsite sampled (Appendix 2). However, the occurrence of species turnover between campsites on the same island is consistent with the significance of geographical distance as an isolating factor, even in the absence of marine barriers.

\section{PATTERNS IN COMPOSITION OF THE GENERA}

At the level of genus, patterns in composition of camaenid land snail assemblages also appeared to correspond largely with a rainfall gradient. Islands with a high average annual rainfall contained a higher number of genera that are characteristic of the wettest part of the Kimberley (i.e. central area of its north-west) and restricted to rainforest habitats, whereas the lower rainfall islands located in the north-eastern and southern-most sections along the coastline contain genera that have distributions that extend into semi-arid areas and will also occur in more open woodland (Solem 1991; Solem and McKenzie 1991; Köhler 2011b). The close association of rainfall with species composition of land snails has also been observed in many other countries (e.g. Hermida et al. 1994; Kadmon and Heller 1998; Tattersfield et al. 2001; Steinitz et al. 2005), and is likely to be an indirect effect with rainfall determining the soil moisture, vegetation and productivity at a site (Nekola 2003; Chiba 2007; Slatyer et al. 2007).

The extent of rock scree also played a role in terms of explaining assemblage composition. Genera containing species less reliant on rock scree have a higher representation in one of the island groups identified. Specifically, two of the three genera in one of the groups (Xanthomelon and Rhagada) contain species that are free-sealers (i.e. to avoid desiccation they secrete mucus across their shell opening), as opposed to a rock-sealer (which seals with mucus to a rock), and therefore are not dependent on rock scree to provide shelter during aestivation, but can burrow in soil or leaf litter (Solem and McKenzie 1991). Island area and insularity did not appear to contribute to the patterns in assemblage composition observed, however, these attributes are more likely to play a role in determining species diversity (as evidenced above).

The 'distance decay' pattern, where sites located in close proximity to each other tend to have more species in common than sites separated by large distances, has been attributed to a combination of environmental relationships and dispersal processes (Nekola and White 1999). This pattern is expected to be stronger for organisms with poor dispersal ability (Steinitz et al. 2006). In this case, we found little evidence of distance decay among camaenid species, although we did find the pattern at the higher taxonomic resolution of genus, suggesting that geographic distances between islands played a role in defining compositional groups at this resolution. However, rainfall and rock scree still influenced composition even after controlling for geographical distance indicating a combined effect of all these factors.

Among camaenid land snails, sympatric species have been shown to belong to different genera, with each genus displaying unique adaptations with respect to aestivation behavior, body size or shell shape, suggesting that they use distinct ecological niches (Solem 1985). Studies of land snails elsewhere have shown that even within a genus, shell morphology of the species has a clear relationship with habitat use (Cameron and Cook 1989; Chiba 2004; Stankowski 2011). For instance, high-spired shells are generally associated with vertical services and flat shells with horizontal surfaces (Barker 2001). Our study also showed that co-occurring genera among the islands do tend to have a different shell shape (i.e. as indicated by height $\mathrm{v}$ diameter). Additionally, those genera that share a similar shell shape generally belong to different compositional groups (Figure 5). In this case, we used a 'broadbrush' approach and averaged the shell dimensions for each genus regardless of the island they occurred on and related that to the compositional pattern. Even so, the standard errors were very small (Appendix 3). This result indicates that species coexistence of camaenid land snails could be related to niche differentiation. Further studies will investigate co-occurring species on islands, relating shell morphology specifically to habitat/substrate preference. 
NON-CAMAENID LAND SNAILS

\section{CORRELATES OF SPECIES RICHNESS}

For the more widely distributed non-camaenid land snail species, annual rainfall was again the most important attribute defining species richness, with the model including rainfall alone explaining $65 \%$ of the deviance. While many of these species are known to tolerate a variety of environmental conditions (Solem 1988b; Cameron 1992), the patches of rainforest of the high rainfall zone are optimal habitat for land snails in general (for reasons explained above).

The confounding effect of sampling effort on species richness was evidenced here, with the influence of sampling effort moderately supported in the models. The small size of the non-camaenid species $(1-10 \mathrm{~mm})$ and the large proportion of arboreal species (Solem and McKenzie 1991) make them particularly difficult to detect. The vast majority of non-camaenids are found by searching through leaf litter, where they can be easily overlooked (V. Kessner, pers. comm.). Sampling effort therefore, is likely to bias estimates of species richness to some degree. However, among the islands as a whole, the species accumulation curve does not indicate gross deficiencies.

The remaining attributes, including island area and distance to a larger landmass, were only weakly supported in terms of explaining species richness. However, the high passive dispersal capacity of the non-camaenids, including their ability to cross substantial barriers such as the ocean (Solem and McKenzie 1991; Cameron 1992), and the relatively small distances between the islands and the mainland (majority less than $4 \mathrm{~km}$ ), permits colonisation into most areas supporting suitable habitat. This pattern is typical of other groups with high passive dispersal such as perennial plants, as well as highly mobile species such as birds (McKenzie et al. 1991b; Steinitz et al. 2006). The lack of obvious speciation of the noncamaenids on the islands also suggests a high dispersal rate, as sufficient gene flow between islands will prevent divergence of populations (Losos and Ricklefs 2009). Lack of evidence of diversification also points to extinction/colonisation dynamics, rather than within-island speciation, as the main driver of species diversity of the noncamaenid land snails on the islands.

\section{PATTERNS IN SPECIES COMPOSITION}

In contrast to the extraordinarily high inter-island turnover in the camaenid species, a large majority of the non-camaenid species were recorded on several islands. This difference in geographical range has been attributed to the ease of passive dispersal of the smaller non-camaenid species (Solem and McKenzie 1991; Cameron 1992). A significant negative correlation between body size and range size has been recorded for other groups of land snails also implying that dispersal capacity is correlated with body size (Hausdorf 2000; Pokryszko et al. 2011).

Like the camaenids, patterns in species composition of the non-camaenids were tightly correlated with average annual rainfall with the highest number of co-occurring species on islands (>11) receiving at least $1,000 \mathrm{~mm}$ and islands that support low numbers of species $(<4)$ receiving less than $850 \mathrm{~mm}$. A cohort of species tended to occur across all islands, regardless of rainfall, while another appeared to be largely restricted to high rainfall islands. This pattern may in part be due to false absences as indicated by the correlation between species richness and sampling effort. However, rainfall was still the most important attribute influencing species richness, and it is also likely to be a significant driver of species compositional patterns. Solem and McKenzie (1991) also determined rainfall to be the most significant factor influencing species compositional patterns of the non-camaenids within rainforests of the Kimberley more generally.

Patterns in similarity of species composition of the non-camaenids were also influenced by geographical distance between islands. Rainfall still influenced species composition, even after controlling for geographical distance, indicating that both dispersal characteristics of the noncamaenids and a rainfall gradient influenced compositional similarity.

\section{CONCLUSIONS AND CONSERVATION IMPLICATIONS}

As has been found on the Kimberley mainland, the camaenid land snails demonstrated high overall species richness, restricted geographical ranges (most to a single island) and almost complete turnover of species among islands. In comparison, the overall number of the smaller non-camaenid land snail species was much lower and their wider distribution was reflected by a lower level of species turnover among islands. These results are consistent with the differing dispersal abilities of the two groups, one fostering in situ speciation and the other inter-island colonisation. An examination of phylogenetic patterns will help to elucidate this pattern further and will be the subject of another study (authors, unpublished data). We also show that dispersal ability was not the only driver of species richness and composition of land snail species on islands, but that rainfall, island area and availability of habitat also played a role. 
The high level of short-range endemism of the camaenid land snails on the islands sampled, in sharp contrast to the wide ranges of the noncamaenids, implies that conservation effort should be focused on the former. However, as similar environmental attributes were important determinants of species richness and patterns of species composition for both groups of snails, conservation strategies specified for the camaenids are also likely to benefit the noncamaenid land snails.

Of the 89 camaenid species detected in this study, 73 were endemic to the islands, many to single islands. This high level of endemism coupled with such a high turnover rate among islands indicates that all the islands sampled are significant in terms of representing the diversity of the camaenid fauna. This is a conservation issue for many range-restricted endemic fauna (Harvey 2002). In terms of prioritising islands for land snail conservation, those located in the high rainfall zone (i.e. $>1,000 \mathrm{~mm}$ ), are clearly important. Among these, the relatively larger islands and those with a greater extent of rock scree are of particular significance, such as Boongaree, Augustus, Bigge and Storr. To encompass differences in composition, at least at the level of genus, Middle Osborn, Coronation and Wargul Wargul are also priorities. Additionally, some islands contain endemic genera known only from there, such as NW Molema (Molema), Bigge (Kimberleydiscus) and Middle Osborn (Kimberleymelon).

\section{ACKNOWLEDGEMENTS}

Special thanks are due to Vince Kessner for providing invaluable help with sorting, identifying and shipping of vast quantities of study material during the past three years. The Kimberley Island Survey involved many people and we wish to thank our colleagues from the Department of Environment and Conservation, Western Australian Museum, Australian Museum, Kimberley Land Council and Biota Environmental Sciences, the participating Traditional Owners, Aboriginal Rangers and base camp volunteers who contributed to the successful implementation of the field work. We thank the crew of MV Kimberley Escape, MV Odyssey and pilots from Heliwork and Broome Helicopters for transporting teams safely on and off islands. We are grateful to the Regional staff from the Kununurra and Broome Districts for their support during the project. Department of Environment and Conservation staff based at the Mitchell River National Park provided valuable logistic support. The project was possible through a research agreement with the Kimberley Land Council for the Balanggarra, BardiJawi, Dambimangari, Mayala and Uunguu native title claim groups. Funding was provided by the Natural Heritage Trust and the Western Australian Department of Environment and Conservation.

\section{REFERENCES}

Barker, G.M. (2001). Gastropods on land: Phylogeny, diversity and adaptive morphology. In: Barker, G.M, (ed.), The biology of terrestrial molluscs, 1-147. CABI Publishing, Wallingford, NZ.

Belbin, L. (1980). TWOSTEP: a program incorporating asymmetric comparisons that uses two steps to produce a dissimilarity matrix. CSIRO Division of Land Use Research Technical Memorandum 80/9. CSIRO, Canberra, ACT.

Belbin, L. (1995). Technical reference: PATN pattern analysis package. Division of Wildlife Ecology CSIRO, Canberra, ACT.

Bowler, J.M. (1982). Aridity in the late Tertiary and Quaternary of Australia. In: Barker, W.R. and Greenslade, P.J.M, (eds.), Evolution of the flora and fauna of arid Australia, 35-45. Peacock Publishers, Freeville, SA.

Burnham, K.P. and Anderson, D.R. (2002). Model selection and multimodel inference: a practical information-theoretic approach. Second edition. Springer, New York.

Cameron, R. (1992). Land snail faunas of the Napier and Oscar Ranges, Western Australia; diversity, distribution and speciation. Biological Journal of the Linnean Society 45: 271-286.

Cameron, R. and Cook, L. (1989). Shell size and shape in Madeiran land snails: do niches remain unfilled? Biological Journal of the Linnean Society 36: 79-96.

Chiba, S. (2004). Ecological and morphological patterns in communities of land snails of the genus Mandarina from the Bonin Islands. Journal of Evolutionary Biology 17: 131-143.

Chiba, S. (2007). Species richness patterns along environmental gradients in island land Molluscan fauna. Ecology 88: 1738-1746.

Clarke, K.R. and Gorley, R.N. (2006). PRIMER v6: User Manual/Tutorial. PRIMER-E Ltd, Plymouth.

Clarke, K.R., Somerfield, P.J. and Chapman, M.G. (2006). On resemblance measures for ecological studies, including taxonomic dissimilarities and a zero-adjusted Bray-Curtis coefficient for denuded assemblages. Journal of Experimental Marine Biology and Ecology 330: 55-80.

Clements, R., Ng, P.K.L., Lu, X.X., Ambu, S., Schilthuizen, M. and Bradshaw, C.J.A. (2008). Using biogeographical patterns of endemic land snails to improve conservation planning for limestone karsts. Biological Conservation 141: 2751-2764.

Cook, L.M. (2008). Species richness in Madeiran land snails, and its causes. Journal of Biogeography 35: 647-653.

Couper, P.J. and Hoskin, C.J. (2008). Litho-refugia: the importance of rock landscapes for the long-term persistence of Australian rainforest fauna. Australian Zoologist 34: 554-560.

Cowie, R.H. (1995). Variation in species diversity and shell shape in Hawaiian land snails: in situ speciation 
and ecological relationships. Evolution 49: 1191-1202.

Geffen, E., Anderson, M.J. and Wayne R.K. (2004). Climate and habitat barriers to dispersal in the highly mobile grey wolf. Molecular Ecology 13: 2481-2490.

Gibson, L.A. and McKenzie, N.L. (2012). Identification of biodiversity assets of selected Kimberley islands: background and implementation. Records of the Western Australian Museum, Supplement 81: 1-12.

Harvey, M.S. (2002). Short-range endemism amongst the Australian fauna: some examples from non-marine environments. Invertebrate Systematics 16: 555-570.

Hausdorf, B. (2000). Biogeography of the Limacoidea sensu lato (Gastropoda: Stylommatophora): vicariance events and long-distance dispersal. Journal of Biogeography 27: 379-390.

Hermida, J., Outeiro, A. and Rodriguez, T. (1994). Biogeography of terrestrial gastropods of north-west Spain. Journal of Biogeography 21: 207-217.

Houlder, D., Hutchinson, M., Nix, H. and McMahon, J. (2000). ANUCLIM User Guide. Centre for Resource and Environmental Studies. Australian National University, Canberra.

Johnson, M.S., O’Brien, E.K. and Fitzpatrick, J.J. (2010). Deep, hierarchical divergence of mitochondrial DNA in Amplirhagada land snails (Gastropoda: Camaenidae) from the Bonaparte Archipelago, Western Australia. Biological Journal of the Linnean Society 100: 141-153.

Kadmon, R. and Heller, J. (1998). Modelling faunal responses to climatic gradients with GIS: land snails as a case study. Journal of Biogeography 25: 527-539.

Köhler, F. (2010a). Three new species and two new genera of land snails from the Bonaparte Archipelago in the Kimberley, Western Australia (Pulmonata, Camaenidae). Molluscan Research 30: 1-16.

Köhler, F. (2010b). Uncovering local endemism in the Kimberley, Western Australia: description of new species of the genus Amplirhagada Iredale, 1933 (Pulmonata: Camaenidae). Records of the Australian Museum 62: 217-284.

Köhler, F. (2011a). Australocosmica, a new genus of land snails from the Kimberley, Western Australia (Eupulmonata, Camaenidae). Malacologia 53: 199-216.

Köhler, F. (2011b). The camaenid species of the Kimberley Islands, Western Australia (Stylommatophora: Helicoidea). Malacologia 54: 203-406.

Köhler, F. (2011c). Descriptions of new species of the diverse and endemic land snail Amplirhagada Iredale, 1933 from rainforest patches across the Kimberley, Western Australia (Pulmonata, Camaenidae). Records of the Australian Museum 63: 167-202.

Köhler, F., Kessner, V. and Whisson, C. (2012). New records of non-marine, non-camaenid gastropods from islands off the Kimberley coast, Western Australia. Records of the Western Australian Museum in press.

Losos, J.B. and Ricklefs, R.E. (2009). Adaptation and diversification on islands. Nature 457: 830-836.

Losos, J.B. and Ricklefs, R.E. (2010). The Theory of Island Biogeography Revisited. Princeton University Press, New Jersey.

Losos, J.B. and Schluter, D. (2000). Analysis of an evolutionary species-area relationship. Nature 408:
$847-850$.

May, J.E. and McKenzie, N.L. (eds) (2002). A Biodiversity Audit of Western Australia's Biogeographical Subregions in 2002. Department of Conservation and Land Management, Perth.

McKenzie, N.L, Johnston, R.B. and Kendrick P.G. (1991a). Kimberley Rainforests of Australia. Surrey Beatty \& Sons, Chipping Norton, New South Wales, Australia.

McKenzie, N.L, Belbin, L., Keighery, G.J. and Kenneally, K.F. (1991b). Kimberley rainforest communities: patterns of species composition and Holocene biogeography. In: McKenzie, N.L., Johnston, R.B. and Kendrick, P.G. (eds), Kimberley Rainforests of Australia, 423-451. Surrey Beatty \& Sons, Chipping Norton, New South Wales, Australia.

Nekola, J.C. (2003). Large-scale terrestrial gastropod community composition patterns in the Great Lakes region of North America. Diversity and Distributions 9: $55-71$.

Nekola, J.C. and White, P.S. (1999). The distance decay of similarity in biogeography and ecology. Journal of Biogeography 26: 867-878.

Overton, J.M.C., Barker, G.M. and Price, R. (2009). Estimating and conserving patterns of invertebrate diversity: a test case of New Zealand land snails. Diversity and Distributions 15: 731-41.

Parent, C.E. and Crespi, B.J. (2006). Sequential colonization and diversification of Galapagos endemic land snail genus Bulimulus (Gastropoda, Stylommatophora). Evolution 60: 2311-2328.

Pokryszko, B.M. (1996). The Gastrocoptinae of Australia (Gastropoda: Pulmonata: Pupilloidea): systematics, distribution and origin. Invertebrate Taxonomy 10: 1085-1150.

Pokryszko, B.M., Cameron, R.A.D., Mumladze, L. and Tarkhnishvili, D. (2011). Forest snail faunas from Georgian Transcaucasia: patterns of diversity in a Pleistocene refugium. Biological Journal of the Linnean Society 102: 239-250.

R Development Core Team (2009). R: A language and environment for statistical computing. R Foundation for Statistical Computing, Vienna. URL: http://www.Rproject.org.

Rosenberg, M.S. and Anderson, C.D. (2011). PASSaGE: Pattern Analysis, Spatial Statistics and Geographic Exegesis. Version 2. Methods in Ecology and Evolution. 2: 229-232.

Slatyer, C., Ponder, W., Rosauer, D. and Davis, L. (2007). Between a rock and a dry place: land snails in arid Australia. In: C. Dickman, D. Lunney and S. Burgin (eds), Animals of Arid Australia: out on their own? 30-41. Royal Zoological Society of New South Wales, Mosman, New South Wales, Australia.

Sneath, P.H.A. and Sokal, R.R. (1973). Numerical Taxonomy. The Principles and Practice of Numerical Classification. W.H. Freeman, San Francisco, California, USA.

Solem, A. (1981a). Camaenid land snails from Western and central Australia (Mollusca: Pulmonata: Camaenidae). II. Taxa from the Kimberley, Amplirhagada Iredale, 1933. Records of the Western Australian Museum, Supplement 11: 147-320.

Solem, A. (1981b). Camaenid land snails from Western 
and central Australia (Mollusca: Pulmonata: Camaenidae). III. Taxa from the Ningbing Ranges and Nearby Areas. Records of the Western Australian Museum, Supplement 11: 321-425.

Solem, A. (1984). Camaenid land snails from western and central Australia (Mollusca: Pulmonata: Camaenidae). IV. Taxa from the Kimberley, Westraltrachia Iredale, 1933 and related genera. Records of the Western Australian Museum, Supplement 17: 427-705.

Solem, A. (1985). Camaenid land snails from Western and central Australia (Mollusca: Pulmonata: Camaenidae). V. Remaining Kimberley genera and addenda to the Kimberley. Records of the Western Australian Museum, Supplement 20: 707-981.

Solem, A. (1988a). New camaenid land snails from the northeast Kimberley, Western Australia. Journal of the Malacological Society of Australia 9: 27-58.

Solem, A. (1988b). Non-camaenid land snails of the Kimberley and Northern Territory, Australia I. Systematics, affinities and ranges. Invertebrate Systematics 2: 455-604.

Solem, A. (1991). Land snails of Kimberley rainforest patches and biogeography of all Kimberley land snails. In: McKenzie, N.L., Johnston, R.B. and Kendrick, P.G. (eds), Kimberley Rainforests of Australia, 145-245. Surrey Beatty \& Sons, Chipping Norton, New South Wales, Australia.

Solem, A. (1997). Camaenid land snails from Western and central Australia (Mollusca: Pulmonata: Camaenidae). VII. Taxa from Dampierland through to the Nullabor. Records of the Western Australian Museum, Supplement 50: 1461-1906.

Solem, A. and McKenzie N.L. (1991). The composition of land snail assemblages in Kimberley rainforests. In: McKenzie, N.L., Johnston, R.B. and Kendrick, P.G. (eds), Kimberley Rainforests of Australia, 247-263. Surrey Beatty \& Sons, Chipping Norton, New South Wales, Australia.

Stanisic , J., Cameron, R.A.D., Pokryszko, B.M. and Nekola, J.C. (2007). Forest snail faunas from S.E. Queensland and N.E. New South Wales (Australia): patterns of local and regional richness and differentiation. Malacologia 49: 445-462.

Stanisic, J., Shea, M., Potter, D. and Griffiths, O. (2010). Australian land snails Volume 1. A field guide to eastern Australian species. Bioculture Press, Riviere des Anguilles, Mauritius.

Stankowski, S. (2011). Extreme, continuous variation in an island snail: local diversification and association of shell form with the current environment. Biological Journal of the Linnean Society 104, 756-769.

Steinitz, O., Heller, J., Tsoar, A., Rotem, D. and Kadmon, R. (2005). Predicting regional patterns of similarity in species composition for conservation planning. Conservation Biology 19: 1978-1988.

Steinitz, O., Heller, J., Tsoar, A., Rotem, D. and Kadmon, R. (2006). Environment, dispersal and patterns of species similarity. Journal of Biogeography 33: 10441054

Tattersfield, P., Warui, C., Seddon, M. and Kiringe, J. (2001). Land snail faunas of afromontane forests of Mount Kenya, Kenya: ecology, diversity and distribution patterns. Journal of Biogeography 28: 843-861.

Triantis, K., Mylonas, M., Weiser, M., Lika, K. and Vardinoyannis, K. (2005). Species richness, environmental heterogeneity and area: a case study based on land snails in Skyros archipelago (Aegean Sea, Greece). Journal of Biogeography 32: 1727-1735.

Welter-Schultes, F. and Williams, M. (1999). History, island area and habitat availability determine land snail species richness of Aegean islands. Journal of Biogeography 26: 239-249.

Wintle, B., Elith, J. and Potts, J. (2005). Fauna habitat modelling and mapping: a review and case study in the Lower Hunter Central Coast region of NSW. Austral Ecology 30: 719-738.

MANUSCRIPT RECEIVED OCTOBER 2011; ACCEPTED NOVEMBER 2011. 
APPENDIX 1 Camaenid land snail species recorded on islands along the Kimberley coast.

Abbreviations: AD - Adolphus, AU - Augustus, BI - Bigge, BO - Boongaree, BM - Byam Martin, CO - Coronation, HI - Hidden, JU - Jungulu, KA - Katers, KF - Kingfisher, LA - Lachlan, LO - Long, MA - Mary, MO - Middle Osborn, NM - NW Molema, GM - Sir Graham Moore, SO - South West Osborn, AN - St Andrew, ST - Storr, SU - Sunday, UN - Unnamed, UW - Uwins, WW - Wargul Wargul, WU - Wulalam

Species

AD AU BI BO BM CO HI JU KA KF LA LO MA MO NM GM SO AN ST SU UN UW WW WU

Amplirhagada alkuonides

$\begin{array}{llllllllllllllllllllllll}0 & 0 & 0 & 0 & 0 & 0 & 0 & 0 & 0 & 1 & 0 & 0 & 0 & 0 & 0 & 0 & 0 & 0 & 0 & 0 & 0 & 0 & 0 & 0\end{array}$

Amplirhagada astuta

$\begin{array}{llllllllllllllllllllllll}0 & 0 & 0 & 0 & 0 & 0 & 0 & 0 & 0 & 0 & 0 & 0 & 0 & 0 & 1 & 0 & 0 & 0 & 0 & 0 & 0 & 0 & 0 & 0\end{array}$

Amplirhagada basilica

$\begin{array}{llllllllllllllllllllllll}0 & 1 & 0 & 0 & 0 & 0 & 0 & 0 & 0 & 0 & 0 & 0 & 0 & 0 & 0 & 0 & 0 & 0 & 0 & 0 & 0 & 0 & 0 & 0\end{array}$

Amplirhagada boongareensis

$\begin{array}{llllllllllllllllllllllll}0 & 0 & 0 & 1 & 0 & 0 & 0 & 0 & 0 & 0 & 0 & 0 & 0 & 0 & 0 & 0 & 0 & 0 & 0 & 0 & 0 & 0 & 0 & 0\end{array}$

Amplirhagada burrowsena

$\begin{array}{llllllllllllllllllllllll}0 & 0 & 0 & 0 & 0 & 0 & 0 & 0 & 0 & 0 & 0 & 0 & 0 & 0 & 0 & 0 & 0 & 0 & 0 & 0 & 0 & 0 & 1 & 0\end{array}$

Amplirhagada camdenensis

$\begin{array}{llllllllllllllllllllllll}0 & 1 & 0 & 0 & 0 & 0 & 0 & 0 & 0 & 0 & 0 & 0 & 0 & 0 & 0 & 0 & 0 & 0 & 0 & 0 & 0 & 0 & 0 & 0\end{array}$

Amplirhagada decora

$\begin{array}{llllllllllllllllllllllll}0 & 0 & 1 & 0 & 0 & 0 & 0 & 0 & 0 & 0 & 0 & 0 & 0 & 0 & 0 & 0 & 0 & 0 & 0 & 0 & 0 & 0 & 0 & 0\end{array}$

Amplirhagada euroa

$\begin{array}{llllllllllllllllllllllll}1 & 0 & 0 & 0 & 0 & 0 & 0 & 0 & 0 & 0 & 0 & 0 & 0 & 0 & 0 & 0 & 0 & 0 & 0 & 0 & 0 & 0 & 0 & 0\end{array}$

Amplirhagada gibsoni

$\begin{array}{llllllllllllllllllllllll}0 & 0 & 0 & 1 & 0 & 0 & 0 & 0 & 0 & 0 & 0 & 0 & 0 & 0 & 0 & 0 & 0 & 0 & 0 & 0 & 0 & 0 & 0 & 0\end{array}$

Amplirhagada indistincta

$\begin{array}{llllllllllllllllllllllll}0 & 0 & 0 & 0 & 0 & 0 & 0 & 0 & 0 & 0 & 0 & 0 & 0 & 0 & 0 & 0 & 1 & 0 & 0 & 0 & 0 & 0 & 0 & 0\end{array}$

Amplirhagada katerana

$\begin{array}{llllllllllllllllllllllll}0 & 0 & 0 & 0 & 0 & 0 & 0 & 0 & 1 & 0 & 0 & 0 & 0 & 0 & 0 & 0 & 0 & 0 & 0 & 0 & 0 & 0 & 0 & 0\end{array}$

Amplirhagada kessneri

$\begin{array}{llllllllllllllllllllllll}0 & 0 & 1 & 0 & 0 & 0 & 0 & 0 & 0 & 0 & 0 & 0 & 0 & 0 & 0 & 0 & 0 & 0 & 0 & 0 & 0 & 0 & 0 & 0\end{array}$

Amplirhagada pusilla

$\begin{array}{llllllllllllllllllllllll}0 & 0 & 0 & 0 & 0 & 0 & 0 & 0 & 0 & 0 & 0 & 0 & 0 & 0 & 0 & 0 & 0 & 1 & 0 & 0 & 0 & 0 & 0 & 0\end{array}$

Amplirhagada regia

$\begin{array}{llllllllllllllllllllllll}0 & 0 & 0 & 1 & 0 & 0 & 0 & 0 & 0 & 0 & 0 & 0 & 0 & 0 & 0 & 0 & 0 & 0 & 0 & 0 & 0 & 0 & 0 & 0\end{array}$

Amplirhagada sinenomine

$\begin{array}{llllllllllllllllllllllll}0 & 0 & 0 & 0 & 0 & 0 & 0 & 0 & 0 & 0 & 0 & 0 & 0 & 0 & 0 & 0 & 0 & 0 & 0 & 0 & 1 & 0 & 0 & 0\end{array}$

Amplirhagada solemiana

$\begin{array}{llllllllllllllllllllllll}0 & 0 & 0 & 0 & 0 & 0 & 0 & 0 & 0 & 0 & 0 & 0 & 0 & 1 & 0 & 0 & 0 & 0 & 0 & 0 & 0 & 0 & 0 & 0\end{array}$

Amplirhagada sp.

$\begin{array}{llllllllllllllllllllllll}0 & 0 & 0 & 1 & 0 & 0 & 0 & 0 & 0 & 0 & 0 & 0 & 0 & 0 & 0 & 0 & 0 & 0 & 0 & 0 & 0 & 0 & 0 & 0\end{array}$

Amplirhagada sphaeroidea

$\begin{array}{llllllllllllllllllllllll}0 & 0 & 0 & 0 & 0 & 0 & 0 & 0 & 0 & 0 & 0 & 0 & 0 & 0 & 0 & 0 & 0 & 1 & 0 & 0 & 0 & 0 & 0 & 0\end{array}$

Amplirhagada storriana

$\begin{array}{llllllllllllllllllllllll}0 & 0 & 0 & 0 & 0 & 0 & 0 & 0 & 0 & 0 & 0 & 0 & 0 & 0 & 0 & 0 & 0 & 0 & 1 & 0 & 0 & 0 & 0 & 0\end{array}$

Amplirhagada uwinsensis

$\begin{array}{llllllllllllllllllllllll}0 & 0 & 0 & 0 & 0 & 0 & 0 & 0 & 0 & 0 & 0 & 0 & 0 & 0 & 0 & 0 & 0 & 0 & 0 & 0 & 0 & 1 & 0 & 0\end{array}$

Amplirhagada yorkensis

$\begin{array}{llllllllllllllllllllllll}0 & 0 & 0 & 0 & 0 & 1 & 0 & 0 & 0 & 0 & 0 & 0 & 0 & 0 & 0 & 0 & 0 & 0 & 0 & 0 & 0 & 0 & 0 & 0\end{array}$

Australocosmica augustae

$\begin{array}{llllllllllllllllllllllll}0 & 1 & 0 & 0 & 0 & 0 & 0 & 0 & 0 & 0 & 0 & 0 & 0 & 0 & 0 & 0 & 0 & 0 & 0 & 0 & 0 & 0 & 0 & 0\end{array}$ 
Australocosmica spec. A $\begin{array}{llllllllllllllllllllllll}0 & 0 & 0 & 0 & 0 & 0 & 0 & 1 & 0 & 0 & 0 & 0 & 0 & 0 & 0 & 0 & 0 & 0 & 0 & 0 & 0 & 0 & 0 & 0\end{array}$

Australocosmica spec. B $\begin{array}{llllllllllllllllllllllll}0 & 0 & 0 & 0 & 0 & 1 & 0 & 0 & 0 & 0 & 0 & 0 & 0 & 0 & 0 & 0 & 0 & 0 & 0 & 0 & 0 & 0 & 0 & 0\end{array}$

Baudinella boongareensis $\begin{array}{llllllllllllllllllllllll}0 & 0 & 0 & 1 & 0 & 0 & 0 & 0 & 0 & 0 & 0 & 0 & 0 & 0 & 0 & 0 & 0 & 0 & 0 & 0 & 0 & 0 & 0 & 0\end{array}$

Baudinella occidentalis

$\begin{array}{llllllllllllllllllllllll}0 & 0 & 0 & 0 & 0 & 0 & 0 & 1 & 0 & 0 & 0 & 0 & 0 & 0 & 0 & 0 & 0 & 0 & 0 & 0 & 0 & 0 & 0 & 0\end{array}$

Baudinella setobaudinioides

$\begin{array}{llllllllllllllllllllllll}0 & 1 & 0 & 0 & 0 & 0 & 0 & 0 & 0 & 0 & 0 & 0 & 0 & 0 & 0 & 0 & 0 & 0 & 0 & 0 & 0 & 0 & 0 & 0\end{array}$

Baudinella thielei

$\begin{array}{llllllllllllllllllllllll}0 & 0 & 1 & 0 & 0 & 0 & 0 & 0 & 0 & 0 & 0 & 0 & 0 & 0 & 0 & 0 & 0 & 0 & 0 & 0 & 0 & 0 & 0 & 0\end{array}$

Baudinella tuberculata

$\begin{array}{llllllllllllllllllllllll}0 & 0 & 0 & 0 & 0 & 1 & 0 & 0 & 0 & 0 & 0 & 0 & 0 & 0 & 0 & 0 & 0 & 0 & 0 & 0 & 0 & 0 & 0 & 0\end{array}$

Carinotrachia admirale

$\begin{array}{llllllllllllllllllllllll}0 & 0 & 0 & 0 & 0 & 0 & 0 & 0 & 0 & 0 & 0 & 0 & 0 & 1 & 0 & 0 & 0 & 0 & 0 & 0 & 0 & 0 & 0 & 0\end{array}$

Carinotrachia elevata

$\begin{array}{llllllllllllllllllllllll}0 & 0 & 0 & 0 & 0 & 0 & 0 & 0 & 0 & 0 & 0 & 0 & 0 & 0 & 0 & 0 & 1 & 0 & 0 & 0 & 0 & 0 & 0 & 0\end{array}$

Globorhagada confusa

$\begin{array}{llllllllllllllllllllllll}0 & 0 & 0 & 0 & 0 & 0 & 0 & 0 & 1 & 0 & 0 & 0 & 0 & 0 & 0 & 0 & 0 & 0 & 0 & 0 & 0 & 0 & 0 & 0\end{array}$

Globorhagada wunandarra

$\begin{array}{llllllllllllllllllllllll}0 & 0 & 0 & 1 & 0 & 0 & 0 & 0 & 0 & 0 & 0 & 0 & 0 & 0 & 0 & 0 & 0 & 0 & 0 & 0 & 0 & 0 & 0 & 0\end{array}$

Globorhagada prudhoensis

$\begin{array}{llllllllllllllllllllllll}0 & 0 & 1 & 0 & 0 & 0 & 0 & 0 & 0 & 0 & 0 & 0 & 0 & 0 & 0 & 0 & 0 & 0 & 0 & 0 & 0 & 0 & 0 & 0\end{array}$

Globorhagada uwinsensis

$\begin{array}{llllllllllllllllllllllll}0 & 0 & 0 & 0 & 0 & 0 & 0 & 0 & 0 & 0 & 0 & 0 & 0 & 0 & 0 & 0 & 0 & 0 & 0 & 0 & 0 & 1 & 0 & 0\end{array}$

Globorhagada wurroolgu

$\begin{array}{llllllllllllllllllllllll}0 & 1 & 0 & 0 & 0 & 0 & 0 & 1 & 0 & 0 & 0 & 0 & 0 & 0 & 0 & 0 & 0 & 0 & 0 & 0 & 0 & 0 & 0 & 0\end{array}$

Globorhagada yoowadan

$\begin{array}{llllllllllllllllllllllll}0 & 0 & 0 & 0 & 0 & 0 & 0 & 0 & 0 & 0 & 0 & 0 & 0 & 0 & 0 & 0 & 0 & 0 & 1 & 0 & 1 & 0 & 0 & 0\end{array}$

Globorhagada sp.

$\begin{array}{llllllllllllllllllllllll}0 & 0 & 0 & 0 & 0 & 1 & 0 & 0 & 0 & 0 & 0 & 0 & 0 & 0 & 0 & 0 & 0 & 0 & 0 & 0 & 0 & 0 & 0 & 0\end{array}$

Kimberleydiscus fasciatus

$\begin{array}{llllllllllllllllllllllll}0 & 0 & 1 & 0 & 0 & 0 & 0 & 0 & 0 & 0 & 0 & 0 & 0 & 0 & 0 & 0 & 0 & 0 & 0 & 0 & 0 & 0 & 0 & 0\end{array}$

Kimberleymelon tealei

$\begin{array}{llllllllllllllllllllllll}0 & 0 & 0 & 0 & 0 & 0 & 0 & 0 & 0 & 0 & 0 & 0 & 0 & 1 & 0 & 0 & 0 & 0 & 0 & 0 & 0 & 0 & 0 & 0\end{array}$

Kimberleytrachia aequum

$\begin{array}{llllllllllllllllllllllll}0 & 0 & 0 & 1 & 0 & 0 & 0 & 0 & 0 & 0 & 0 & 0 & 0 & 0 & 0 & 0 & 0 & 0 & 0 & 0 & 0 & 0 & 0 & 0\end{array}$

Kimberleytrachia

alphacentauri

$\begin{array}{llllllllllllllllllllllll}0 & 0 & 0 & 1 & 0 & 0 & 0 & 0 & 0 & 0 & 0 & 0 & 0 & 0 & 0 & 0 & 0 & 0 & 0 & 0 & 0 & 0 & 0 & 0\end{array}$

Kimberleytrachia

amplirhagadoides

$\begin{array}{llllllllllllllllllllllll}0 & 1 & 0 & 0 & 0 & 0 & 0 & 0 & 0 & 0 & 0 & 0 & 0 & 0 & 0 & 0 & 0 & 0 & 0 & 0 & 0 & 0 & 0 & 0\end{array}$

Kimberleytrachia achernaria

$\begin{array}{llllllllllllllllllllllll}0 & 1 & 0 & 0 & 0 & 0 & 0 & 0 & 0 & 0 & 0 & 0 & 0 & 0 & 0 & 0 & 0 & 0 & 0 & 0 & 0 & 0 & 0 & 0\end{array}$

Kimberleytrachia canopi

$\begin{array}{llllllllllllllllllllllll}0 & 0 & 0 & 1 & 0 & 0 & 0 & 0 & 0 & 0 & 0 & 0 & 0 & 0 & 0 & 0 & 0 & 0 & 0 & 0 & 0 & 0 & 0 & 0\end{array}$

Kimberleytrachia chartacea

$\begin{array}{llllllllllllllllllllllll}0 & 0 & 0 & 0 & 0 & 0 & 0 & 0 & 0 & 0 & 0 & 0 & 0 & 0 & 0 & 0 & 0 & 0 & 0 & 0 & 0 & 1 & 0 & 0\end{array}$ 


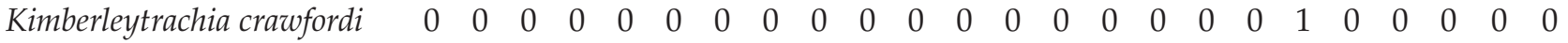

Kimberleytrachia crucis $\quad 00 \begin{array}{lllllllllllllllllllllllll} & 0 & 0 & 0 & 0 & 0 & 0 & 1 & 0 & 0 & 0 & 0 & 0 & 0 & 0 & 0 & 0 & 0 & 0 & 0 & 0 & 0 & 0 & 0\end{array}$

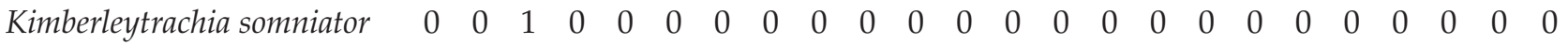

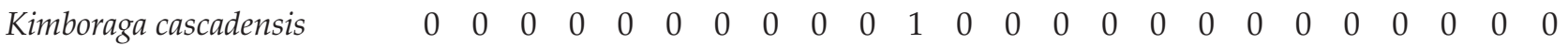

Kimboraga exanima

$\begin{array}{llllllllllllllllllllllll}0 & 0 & 0 & 0 & 0 & 0 & 0 & 0 & 0 & 0 & 0 & 0 & 0 & 0 & 0 & 0 & 0 & 1 & 0 & 0 & 0 & 0 & 0 & 0\end{array}$

Kimboraga glabra

$\begin{array}{llllllllllllllllllllllll}0 & 0 & 0 & 0 & 0 & 1 & 0 & 0 & 0 & 0 & 0 & 0 & 0 & 0 & 0 & 0 & 0 & 0 & 0 & 0 & 0 & 0 & 0 & 0\end{array}$

Kimboraga wulalam

$\begin{array}{llllllllllllllllllllllll}0 & 0 & 0 & 0 & 0 & 0 & 0 & 0 & 0 & 0 & 0 & 0 & 0 & 0 & 0 & 0 & 0 & 0 & 0 & 0 & 0 & 0 & 0 & 1\end{array}$

Molema stankowski

$\begin{array}{llllllllllllllllllllllll}0 & 0 & 0 & 0 & 0 & 0 & 0 & 0 & 0 & 0 & 0 & 0 & 0 & 0 & 1 & 0 & 0 & 0 & 0 & 0 & 0 & 0 & 0 & 0\end{array}$

Retroterra aequabilis

$\begin{array}{llllllllllllllllllllllll}0 & 0 & 0 & 1 & 0 & 0 & 0 & 0 & 0 & 0 & 0 & 0 & 0 & 0 & 0 & 0 & 0 & 0 & 0 & 0 & 0 & 0 & 0 & 0\end{array}$

Retroterra discoidea

$\begin{array}{llllllllllllllllllllllll}0 & 0 & 0 & 0 & 0 & 0 & 0 & 0 & 0 & 0 & 0 & 0 & 0 & 0 & 0 & 0 & 0 & 0 & 0 & 0 & 0 & 1 & 0 & 0\end{array}$

Rhagada biggeana

$\begin{array}{llllllllllllllllllllllll}0 & 0 & 1 & 0 & 0 & 0 & 0 & 0 & 0 & 0 & 0 & 0 & 0 & 0 & 0 & 0 & 0 & 0 & 0 & 0 & 0 & 0 & 0 & 0\end{array}$

Rhagada cygna

$\begin{array}{llllllllllllllllllllllll}0 & 0 & 0 & 0 & 0 & 0 & 1 & 0 & 0 & 0 & 0 & 0 & 0 & 0 & 0 & 0 & 0 & 0 & 0 & 1 & 0 & 0 & 0 & 0\end{array}$

Rhagada dominica

$\begin{array}{llllllllllllllllllllllll}0 & 0 & 0 & 0 & 0 & 0 & 0 & 0 & 0 & 0 & 0 & 0 & 0 & 0 & 0 & 0 & 0 & 0 & 0 & 1 & 0 & 0 & 0 & 0\end{array}$

Rhagada felicitas

$\begin{array}{llllllllllllllllllllllll}0 & 0 & 0 & 0 & 0 & 0 & 0 & 0 & 0 & 0 & 0 & 0 & 0 & 0 & 0 & 0 & 0 & 0 & 1 & 0 & 0 & 0 & 0 & 0\end{array}$

Rhagada kessneri

$\begin{array}{llllllllllllllllllllllll}0 & 1 & 0 & 0 & 0 & 0 & 0 & 0 & 0 & 0 & 0 & 0 & 0 & 0 & 0 & 0 & 0 & 0 & 0 & 0 & 0 & 0 & 0 & 0\end{array}$

Rhagada primigena

$\begin{array}{llllllllllllllllllllllll}0 & 0 & 0 & 0 & 0 & 0 & 0 & 0 & 0 & 0 & 0 & 1 & 0 & 0 & 0 & 0 & 0 & 0 & 0 & 0 & 0 & 0 & 0 & 0\end{array}$

Rhagada sheaei

$\begin{array}{llllllllllllllllllllllll}0 & 0 & 0 & 0 & 1 & 0 & 0 & 0 & 0 & 0 & 0 & 0 & 0 & 0 & 0 & 0 & 0 & 0 & 0 & 0 & 0 & 0 & 0 & 0\end{array}$

Rhagada sp.

$\begin{array}{llllllllllllllllllllllll}0 & 0 & 0 & 1 & 1 & 0 & 0 & 0 & 0 & 0 & 0 & 0 & 0 & 0 & 0 & 0 & 0 & 0 & 0 & 0 & 0 & 0 & 0 & 0\end{array}$

Setobaudinia capillacea

$\begin{array}{llllllllllllllllllllllll}0 & 0 & 0 & 1 & 0 & 0 & 0 & 0 & 0 & 0 & 0 & 0 & 0 & 0 & 0 & 0 & 0 & 0 & 0 & 0 & 0 & 0 & 0 & 0\end{array}$

Setobaudinia garlinju

$\begin{array}{llllllllllllllllllllllll}0 & 0 & 0 & 0 & 0 & 1 & 0 & 0 & 0 & 0 & 0 & 0 & 0 & 0 & 0 & 0 & 0 & 0 & 0 & 0 & 0 & 0 & 0 & 0\end{array}$

Setobaudinia jiriniensis

Setobaudinia joycei

$\begin{array}{llllllllllllllllllllllll}0 & 0 & 0 & 0 & 0 & 0 & 0 & 0 & 0 & 0 & 0 & 0 & 0 & 0 & 0 & 0 & 0 & 1 & 0 & 0 & 0 & 0 & 0 & 0\end{array}$

Setobaudinia karczewski

$\begin{array}{llllllllllllllllllllllll}0 & 0 & 0 & 0 & 0 & 0 & 0 & 0 & 0 & 0 & 0 & 0 & 0 & 0 & 0 & 0 & 0 & 0 & 0 & 0 & 0 & 0 & 0 & 1\end{array}$

Setobaudinia ngurraali

$\begin{array}{llllllllllllllllllllllll}0 & 0 & 0 & 0 & 0 & 0 & 0 & 0 & 0 & 0 & 0 & 0 & 0 & 0 & 1 & 0 & 0 & 0 & 0 & 0 & 0 & 0 & 0 & 0\end{array}$

$\begin{array}{llllllllllllllllllllllll}0 & 0 & 0 & 0 & 0 & 0 & 0 & 0 & 0 & 0 & 0 & 0 & 0 & 1 & 0 & 0 & 0 & 0 & 0 & 0 & 0 & 0 & 0 & 0\end{array}$ 
Setobaudinia quinta $\begin{array}{llllllllllllllllllllllll}0 & 0 & 0 & 0 & 0 & 0 & 0 & 0 & 0 & 0 & 0 & 0 & 0 & 0 & 0 & 0 & 0 & 0 & 1 & 0 & 0 & 0 & 0 & 0\end{array}$

Setobaudinia rectilabrum $\begin{array}{llllllllllllllllllllllll}0 & 0 & 0 & 0 & 0 & 0 & 0 & 0 & 0 & 0 & 0 & 0 & 0 & 0 & 0 & 0 & 0 & 0 & 0 & 0 & 0 & 0 & 1 & 0\end{array}$

Setobaudinia umbadayi $\begin{array}{llllllllllllllllllllllll}0 & 0 & 0 & 0 & 0 & 0 & 0 & 0 & 0 & 0 & 0 & 0 & 0 & 1 & 0 & 0 & 1 & 0 & 0 & 0 & 0 & 0 & 0 & 0\end{array}$

Setobaudinia wuyurru $\begin{array}{llllllllllllllllllllllll}0 & 0 & 1 & 0 & 0 & 0 & 0 & 0 & 0 & 0 & 0 & 0 & 0 & 0 & 0 & 0 & 0 & 0 & 0 & 0 & 0 & 0 & 0 & 0\end{array}$

Setobaudinia sp.

$\begin{array}{llllllllllllllllllllllll}0 & 1 & 0 & 0 & 0 & 0 & 0 & 0 & 0 & 0 & 0 & 0 & 0 & 0 & 0 & 0 & 0 & 0 & 0 & 0 & 0 & 0 & 0 & 0\end{array}$

Torresitrachia allouarni

$\begin{array}{llllllllllllllllllllllll}0 & 1 & 0 & 0 & 0 & 0 & 0 & 0 & 0 & 0 & 0 & 0 & 0 & 0 & 0 & 0 & 0 & 0 & 0 & 0 & 0 & 0 & 0 & 0\end{array}$

Torresitrachia aquilonia

$\begin{array}{llllllllllllllllllllllll}0 & 0 & 0 & 0 & 0 & 0 & 0 & 0 & 0 & 0 & 0 & 0 & 0 & 0 & 0 & 1 & 0 & 0 & 0 & 0 & 0 & 0 & 0 & 0\end{array}$

Torresitrachia brookei

$\begin{array}{llllllllllllllllllllllll}0 & 0 & 0 & 1 & 0 & 0 & 0 & 0 & 0 & 0 & 0 & 0 & 0 & 0 & 0 & 0 & 0 & 0 & 0 & 0 & 0 & 0 & 0 & 0\end{array}$

Torresitrachia dampieri

$\begin{array}{llllllllllllllllllllllll}0 & 0 & 0 & 0 & 0 & 0 & 0 & 0 & 0 & 1 & 0 & 0 & 0 & 0 & 0 & 0 & 0 & 0 & 0 & 0 & 0 & 0 & 0 & 0\end{array}$

Torresitrachia flindersi

$\begin{array}{llllllllllllllllllllllll}0 & 1 & 0 & 0 & 0 & 0 & 0 & 0 & 0 & 0 & 0 & 0 & 0 & 0 & 0 & 0 & 0 & 0 & 0 & 0 & 0 & 0 & 0 & 0\end{array}$

Torresitrachia freycineti

$\begin{array}{llllllllllllllllllllllll}0 & 0 & 0 & 0 & 0 & 0 & 0 & 1 & 0 & 0 & 0 & 0 & 0 & 0 & 0 & 0 & 0 & 0 & 0 & 0 & 0 & 0 & 0 & 0\end{array}$

Torresitrachia girgarinae

$\begin{array}{llllllllllllllllllllllll}0 & 0 & 0 & 0 & 0 & 0 & 1 & 0 & 0 & 0 & 0 & 0 & 0 & 0 & 0 & 0 & 0 & 0 & 0 & 0 & 0 & 0 & 0 & 0\end{array}$

Torresitrachia hartogi

$\begin{array}{llllllllllllllllllllllll}0 & 0 & 0 & 0 & 0 & 0 & 0 & 0 & 0 & 0 & 0 & 0 & 0 & 0 & 1 & 0 & 0 & 0 & 0 & 0 & 0 & 0 & 0 & 0\end{array}$

Torresitrachia houtmani

$\begin{array}{llllllllllllllllllllllll}0 & 0 & 0 & 0 & 0 & 0 & 0 & 0 & 0 & 0 & 0 & 0 & 0 & 0 & 0 & 0 & 0 & 0 & 0 & 0 & 1 & 0 & 0 & 0\end{array}$

Torresitrachia janszi

$\begin{array}{llllllllllllllllllllllll}0 & 0 & 0 & 0 & 0 & 0 & 0 & 0 & 1 & 0 & 0 & 0 & 0 & 0 & 0 & 0 & 0 & 0 & 0 & 0 & 0 & 0 & 0 & 0\end{array}$

Torresitrachia leichhardti

$\begin{array}{llllllllllllllllllllllll}0 & 0 & 0 & 0 & 0 & 0 & 0 & 0 & 0 & 0 & 0 & 0 & 0 & 0 & 0 & 0 & 0 & 0 & 1 & 0 & 0 & 0 & 0 & 0\end{array}$

Torresitrachia tasmani

$\begin{array}{llllllllllllllllllllllll}0 & 0 & 0 & 0 & 1 & 0 & 0 & 0 & 0 & 0 & 0 & 0 & 0 & 0 & 0 & 0 & 0 & 0 & 0 & 0 & 0 & 0 & 0 & 0\end{array}$

Torresitrachia urvillei

$\begin{array}{llllllllllllllllllllllll}0 & 0 & 1 & 0 & 0 & 0 & 0 & 0 & 0 & 0 & 0 & 0 & 0 & 0 & 0 & 0 & 0 & 0 & 0 & 0 & 0 & 0 & 0 & 0\end{array}$

Xanthomelon obliquirugosa

$\begin{array}{llllllllllllllllllllllll}0 & 0 & 0 & 0 & 0 & 0 & 0 & 0 & 0 & 0 & 0 & 0 & 1 & 0 & 0 & 1 & 0 & 0 & 0 & 0 & 0 & 0 & 1 & 0\end{array}$

Total per island

$\begin{array}{llllllllllllllllllllllll}1 & 11 & 9 & 13 & 3 & 6 & 2 & 5 & 3 & 2 & 1 & 1 & 1 & 5 & 4 & 2 & 3 & 4 & 6 & 2 & 3 & 4 & 3 & 2\end{array}$ 
APPENDIX 2 Classification of camaenid land snail species according to their co-occurrences at each island location.

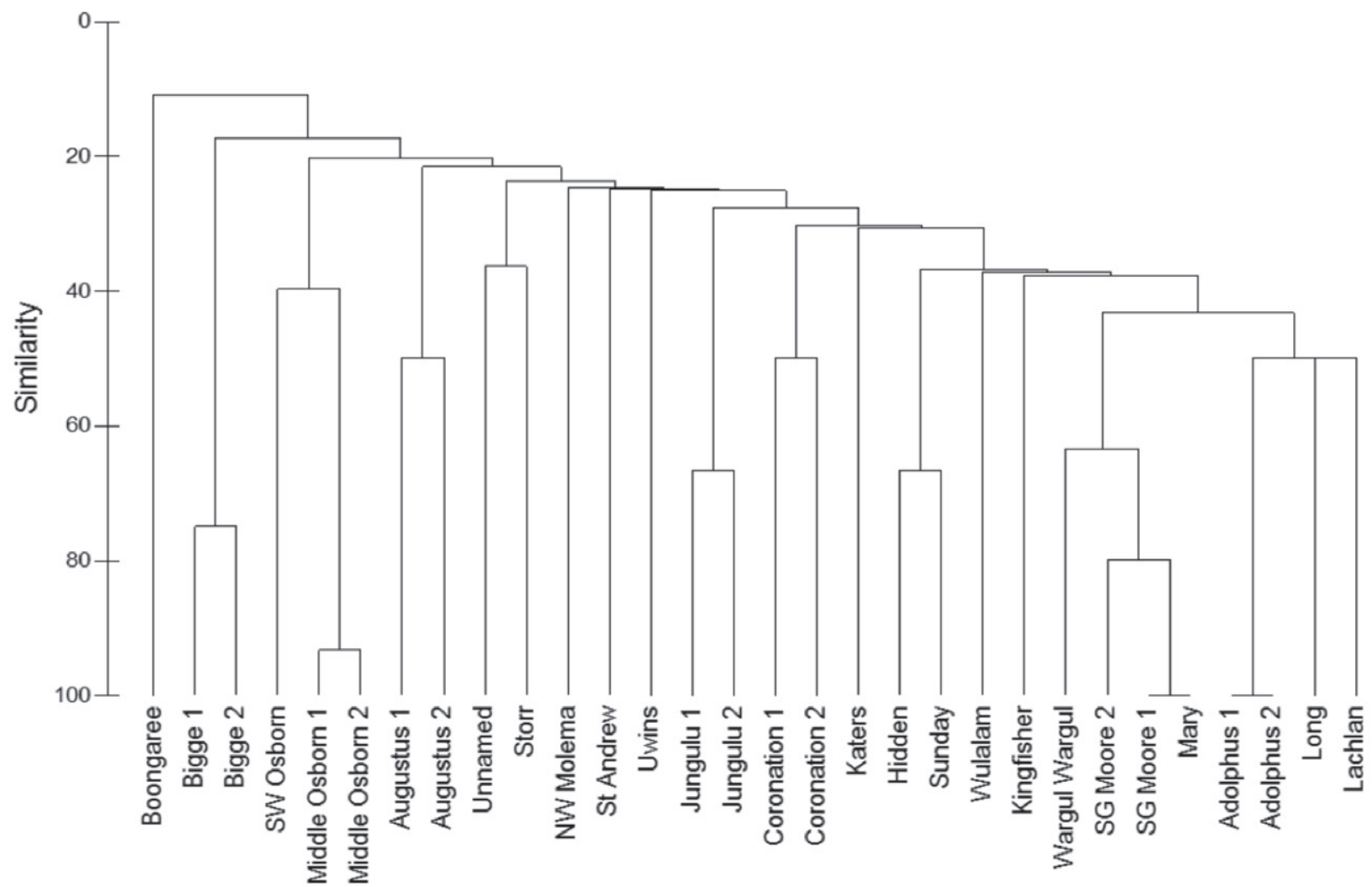

Island locations

APPENDIX 3 Average shell height and diameter of each camaeinid land snail genus across all islands sampled. Standard errors (SE) are also shown.

\begin{tabular}{lllll} 
& Height $(\mathrm{mm})$ & SE & Diameter $(\mathrm{mm})$ & SE \\
\hline Amplirhagada & 15.23 & 0.14 & 20.34 & 0.10 \\
Carinotrachia & 10.27 & 0.08 & 16.95 & 0.11 \\
Kimberleydiscus & 9.23 & 0.17 & 19.28 & 0.26 \\
Kimberleymelon & 21.03 & 0.81 & 23.21 & 0.81 \\
Australocosmica & 11.83 & 0.19 & 15.20 & 0.15 \\
Kimboraga & 16.29 & 0.30 & 21.73 & 0.21 \\
Baudinella & 3.10 & 0.03 & 6.89 & 0.04 \\
Molema & 3.16 & 0.09 & 8.42 & 0.18 \\
Setobaudinia & 4.45 & 0.11 & 8.82 & 0.20 \\
Rhagada & 9.94 & 0.18 & 14.96 & 0.23 \\
Retroterra & 7.76 & 0.48 & 17.70 & 0.42 \\
Kimberleytrachia & 9.45 & 0.34 & 17.17 & 0.52 \\
Torresitrachia & 8.27 & 0.07 & 15.66 & 0.10 \\
Xanthomelon & 22.37 & 0.40 & 24.20 & 0.43 \\
Globorhagada & 27.16 & 0.63 & 25.62 & 0.64 \\
\hline
\end{tabular}

